\title{
Performance of Advanced Automotive Fuel Cell Systems with Heat Rejection Constraint
}

\author{
R.K. Ahluwalia ${ }^{1}$ X. Wang ${ }^{1}$, and A.J. Steinbach ${ }^{2}$ \\ ${ }^{1}$ Argonne National Laboratory, Argonne, IL \\ 23M Fuel Cell Components Program, St. Paul, MN
}

\section{Corresponding Author}

\author{
Rajesh K Ahluwalia \\ Argonne National Laboratory \\ Argonne, IL 60439 \\ Email: walia@anl.gov \\ Phone: (630) 252-5979 \\ Fax: (630) 252-3046
}

\begin{abstract}
Keywords
Polymer electrolyte fuel cells; Heat rejection; Mass transfer in cathode catalysts; Oxygen reduction reaction kinetics; Stability and durability
\end{abstract}

Submitted to the Journal of Power Sources

The submitted manuscript has been created by UChicago Argonne, LLC, Operator of Argonne National Laboratory (“Argonne”). Argonne, a U.S. Department of Energy Office of Science laboratory, is operated under Contract No. DE-AC02-06CH11357. The U.S. Government retains for itself, and others acting on its behalf, a paid-up nonexclusive, irrevocable worldwide license in said article to reproduce, prepare derivative works, distribute copies to the public, and perform publicly and display publicly, by or on behalf of the Government. 


\title{
Performance of Advanced Automotive Fuel Cell Systems with Heat Rejection Constraint
}

\author{
R.K. Ahluwalia ${ }^{1}$, X. Wang ${ }^{1}$, and A.J. Steinbach ${ }^{2}$ \\ ${ }^{1}$ Argonne National Laboratory, Argonne, IL \\ ${ }^{2} 3 \mathrm{M}$ Fuel Cell Components Program, St. Paul, MN
}

\begin{abstract}
Although maintaining polymer electrolyte fuel cells (PEFC) at temperatures below $80^{\circ} \mathrm{C}$ is desirable for extended durability and enhanced performance, the automotive application also requires the PEFC stacks to operate at elevated temperatures and meet the heat rejection constraint, stated as $\mathrm{Q} / \Delta \mathrm{T}<1.45 \mathrm{~kW} /{ }^{\circ} \mathrm{C}$, where $\mathrm{Q}$ is the stack heat load for an $80-\mathrm{kW}_{\mathrm{e}}$ net power PEFC system and $\triangle \mathrm{T}$ is the difference between the stack coolant temperature and $40^{\circ} \mathrm{C}$ ambient temperature. We have developed a method to determine the optimum design and operating conditions for an automotive stack subject to this $\mathrm{Q} / \Delta \mathrm{T}$ constraint, and illustrate it by applying it to a state-of-the-art stack with nano-structured thin film ternary catalysts in the membrane electrode assemblies. In the illustrative example, stack coolant temperatures $>90^{\circ} \mathrm{C}$, stack inlet pressures $>2 \mathrm{~atm}$, and cathode stoichiometries $<2$ are needed to satisfy the $\mathrm{Q} / \Delta \mathrm{T}$ constraint in a cost effective manner. The reference PEFC stack with $0.1 \mathrm{mg} / \mathrm{cm}^{2} \mathrm{Pt}$ loading in the cathode achieves $753 \mathrm{~mW} . \mathrm{cm}^{-2}$ power density at the optimum conditions for heat rejection, compared to $964 \mathrm{~mW} . \mathrm{cm}^{-2}$ in the laboratory cell at the same cell voltage $(663 \mathrm{mV})$ and pressure $(2.5 \mathrm{~atm})$ but lower temperature $\left(85^{\circ} \mathrm{C}\right)$, higher cathode stoichiometry $(2)$, and $100 \%$ relative humidity.

Keywords: Polymer electrolyte fuel cells; automotive application; heat rejection; kinetic and mass transfer losses.

*Corresponding author: walia@anl.gov; T: 1-630-252-5979; F: 1-630-252-3296
\end{abstract}




\section{Introduction}

Durability and cost are regarded as the major barriers to mass commercialization of polymer electrolyte fuel cells (PEFC) for propulsion of light duty vehicles [1]. The current durability targets include $5,000 \mathrm{~h}$ of driving with less than $10 \%$ loss of performance [2]. Operating automotive fuel cells at temperatures below $70-80^{\circ} \mathrm{C}$ partially alleviates many of the durability concerns. For example, under rapidly varying potentials typical of automotive duty cycles, growth of Pt particles in the cathode catalyst layer, and the associated loss of electrochemical surface area (ECSA) and the catalyst activity for the oxygen reduction reaction (ORR), have been recognized as major degradation mechanisms [3]. The growth of the Pt particles is faster at higher temperature due to the enhanced solubility of Pt in the electrolyte and the accelerated rate of Pt particle coalescence/agglomeration $[4,5]$. Catalyst durability is further exacerbated as $\mathrm{Pt}$ loading in the cathode is reduced to levels $\left(<0.1 \mathrm{mg} . \mathrm{cm}^{-2}\right)$ needed to approach the cost targets. Mass transfer issues at high current densities arise as the Pt loading in the cathode catalyst layers is reduced, and become even more prominent as the catalyst degrades and the ECSA decreases [6]. Similarly, even though the durability of the current generation of perfluorosulfonic acid (PFSA) membranes has greatly improved with chemical stabilization and mechanical reinforcement, the chemical stability of the membranes deteriorates under hot and dry conditions [7]. Finally, loss of hydrophobicity of the gas diffusion layer (GDL) is faster at higher temperatures and water transport can become an issue in the affected membrane electrode assemblies (MEAs) at high current densities [8].

To be competitive with the incumbent internal combustion engines (ICEs), fuel cells must operate over a wide range of ambient temperatures and relative humidities. The Fuel Cell Technical Team of the U.S. DRIVE Partnership that includes car companies conducted a study 
analyzing the dependence of stack power density and heat rejection on stack operating temperature. They concluded that a viable automotive fuel cell system must have the ability to reject the stack waste heat $(\mathrm{Q})$ at rated power and $40^{\circ} \mathrm{C}$ ambient temperature [2]. This requirement has been expressed as a constraint that a nominal $90-\mathrm{kW}_{\mathrm{e}}$ PEFC stack should have $\mathrm{Q} / \Delta \mathrm{T}$ less than $1.45 \mathrm{~kW} /{ }^{\circ} \mathrm{C}$, where $\Delta \mathrm{T}$ is the initial difference between the stack coolant outlet temperature $\left(\mathrm{T}_{\mathrm{c}}\right)$ and the ambient temperature $\left(\mathrm{T}_{\mathrm{a}}\right)$. As will be shown in this paper, the $\mathrm{Q} / \Delta \mathrm{T}$ constraint implicitly requires that the PEFC stack be able to operate at coolant temperatures above $90^{\circ} \mathrm{C}$. This constraint has been enforced to maintain the radiator size and frontal area in fuel cell systems to dimensions typical of passenger vehicles using ICEs for propulsion. The radiator size and frontal area are important parameters that affect packaging, cost, performance and drivability of light duty vehicles. Some of the first-generation fuel cell vehicles had oversized radiators and additional radiators in the front wheel housing. It is understood that in normal drive cycles, only for a limited time will the stack be challenged to $\mathrm{Q} / \Delta \mathrm{T}$ approaching $1.45 \mathrm{~kW} /{ }^{\circ} \mathrm{C}$. According to some studies, the stacks in light duty vehicles will be exposed to temperatures exceeding $90^{\circ} \mathrm{C}$ for less than $\sim 1 \%$ of the $5,000 \mathrm{~h}$ required lifetime $[9,10]$.

The $\mathrm{Q} / \Delta \mathrm{T}$ constraint replaces the previous $55 \%$ stack efficiency target at rated power while avoiding the need to impose an additional target for stack temperature at rated power. The stack heat load is implicitly related to the cell voltage and, hence, the stack efficiency. As a reference, consider a state-of-the-art $90-\mathrm{kWe}$ stack that operates at $0.6 \mathrm{~V}$ cell voltage and $80^{\circ} \mathrm{C}$ for $\sim 51 \%$ stack efficiency and $\mathrm{Q} / \Delta \mathrm{T}=2.44 \mathrm{~kW} /{ }^{\circ} \mathrm{C}$. The $1.45 \mathrm{~kW} /{ }^{\circ} \mathrm{C}$ target can be met by decreasing $\mathrm{Q}$, or increasing $\Delta \mathrm{T}$, or doing both. For lower $\mathrm{Q}$, the stack efficiency can be raised by operating the stack at higher cell voltage. At $80^{\circ} \mathrm{C}$, the required cell voltage for $\mathrm{Q} / \Delta \mathrm{T}=1.45 \mathrm{~kW} /{ }^{\circ} \mathrm{C}$ is $0.76 \mathrm{~V}$; the resulting power density at this high a cell voltage is likely too small (bulky and expensive 
stack) for automotive application. For higher $\Delta \mathrm{T}$, the stack must be operated at higher temperature. At $0.6 \mathrm{~V}$, the required operating temperature to meet the $\mathrm{Q} / \Delta \mathrm{T}$ target is $107^{\circ} \mathrm{C}$; membrane stability, electrocatalyst durability and cell humidification are problematic at this high an operating temperature. The third option is to raise both the cell voltage and the operating temperature. For example, $\mathrm{Q} / \Delta \mathrm{T}=1.45 \mathrm{~kW} /{ }^{\circ} \mathrm{C}$ target can be met by raising the cell voltage to $0.663 \mathrm{~V}$ and the operating temperature to $95^{\circ} \mathrm{C}$. Thus, even though the exact value of the appropriate $\mathrm{Q} / \Delta \mathrm{T}$ constraint may be debatable, the constraint does provide a useful metric for assessing the suitability of PEFC stacks for light-duty vehicles and offers a logical way of evaluating different options available for improving their automotive worthiness.

The purpose of this study is to discuss the impact of the $\mathrm{Q} / \Delta \mathrm{T}$ constraint on the performance and cost of automotive PEFC stacks and systems. The study uses state-of-the-art nanostructured thin film (NSTF) ternary catalyst electrodes for making MEAs. Section 2 describes the experimental characterization of the performance of $50-\mathrm{cm}^{2}$ cells fabricated using these MEAs under a wide range of operating conditions. Sections 3 and 4 describe the development of a cell model and its validation using the data collected in Section 2. In Section 5, the validated cell model is used in a reference PEFC system with all the relevant balance-of-plant (BOP) components to analyze the cost and performance of PEFC systems subject to the $\mathrm{Q} / \Delta \mathrm{T}$ constraint.

\section{Experimental}

Multiple $50-\mathrm{cm}^{2}$ active area single cells were assembled with a $24-\mu \mathrm{m}$ membrane (850 equivalent weight), the $\mathrm{Pt}_{0.68} \mathrm{Co}_{0.30} \mathrm{Mn}_{0.02}$ ternary NSTF catalyst, and $3 \mathrm{M}$ gas diffusion layers (GDL) into a Fuel Cell Technologies test cell containing quad serpentine flow fields. The GDL consisted of a backing paper to which was applied a hydrophobic treatment and an MPL (micro- 
porous layer). All cells had a Pt loading of $0.05 \mathrm{mg} \cdot \mathrm{cm}^{-2}$ in the anode. Duplicate cells had nominal Pt loadings of $0.05,0.1,0.15$ and $0.2 \mathrm{mg} . \mathrm{cm}^{-2}$ in the cathode; the actual Pt loadings in the cathode were $0.054,0.103,0.146$ and $0.186 \mathrm{mg} . \mathrm{cm}^{-2}$. The cells were conditioned using a "thermal cycling" process (TC), described in detail in Steinbach et al [11], which consisted of repeated temperature and voltage cycles over a period of 2-3 days until stable performance was reached.

The experimental campaign was organized as three classes of tests with reference $\mathrm{H}_{2}$ and air inlet pressures of 1.5 (P15), 2.5 (P25) and 3 atm (P30). The reference $\mathrm{H}_{2}$ and air stoichiometries (SR) were 2, i.e., $\mathrm{H}_{2}$ and $\mathrm{O}_{2}$ utilizations were $50 \%$. $\mathrm{P} 15$ tests had $80^{\circ} \mathrm{C}$ reference cell temperature and $65^{\circ} \mathrm{C}$ inlet dew point temperature. $\mathrm{P} 15$ and $\mathrm{P} 25$ tests were conducted on cells with $0.1 \mathrm{mg} \cdot \mathrm{cm}^{-2}$ nominal Pt loading in the cathode. $\mathrm{P} 25$ tests had $85^{\circ} \mathrm{C}$ reference cell temperature and $65^{\circ} \mathrm{C}$ inlet dew point temperature. P30 tests were conducted on cells with $0.15 \mathrm{mg} \cdot \mathrm{cm}^{-2}$ nominal Pt loading in the cathode, $90^{\circ} \mathrm{C}$ reference cell temperature, and $64^{\circ} \mathrm{C}$ reference inlet dew point temperature.

Table 1 summarizes the test matrix for P15, P25 and P30. Eight series of tests were designed to investigate the effects of operating temperature, pressure, relative humidity, cathode stoichiometry $\left(\mathrm{SR}_{\mathrm{c}}\right)$, anode stoichiometry $\left(\mathrm{SR}_{\mathrm{a}}\right)$, start up from cold, and idling conditioning. An additional series of tests was run to investigate the effect of Pt loading in cathode. The $\mathrm{H}_{2}$ and air streams had the same inlet dew point temperature in all tests. Unless explicitly stated otherwise, $\mathrm{SR}_{\mathrm{c}}$ and $\mathrm{SR}_{\mathrm{a}}$ were held at 2 in all tests.

Series 1 tests (T Series) varied the cell temperature from $75^{\circ} \mathrm{C}$ to $90^{\circ} \mathrm{C}$ at $\mathrm{P} 15$ and $\mathrm{P} 25$ and $75^{\circ} \mathrm{C}$ to $95^{\circ} \mathrm{C}$ at $\mathrm{P} 30$ reference conditions. The inlet dew points were pre-determined as a function of pressure, temperature and anode/cathode stoichiometry to maintain 100\% relative humidity (RH) at cell exit. In all tests, humidification water was injected directly into the anode and cathode 
feed streams to reach the set dew points. Also, the outlet RH was not measured but was estimated from the cell operating conditions.

Series 2 tests (P Series) varied the inlet pressure from 1 to $2.5 \mathrm{~atm}$ in P15 and P25 and from 1.5 to 3 atm in P30. The inlet pressure was higher than listed in Table 1 if the target pressure could not be reached even with the backpressure valve completely open to the ambient. As in Series 1 tests, the inlet dew points were adjusted to maintain 100\% RH at cell exit. The P15 and P25 tests are listed together implying that the data are taken at the $\mathrm{P} 15$ reference temperature, $80^{\circ} \mathrm{C}$, but the pressure extends to the $\mathrm{P} 25$ reference pressure, $2.5 \mathrm{~atm}$.

Series 3 tests (RH Series) varied the inlet dew points from 50 to $80^{\circ} \mathrm{C}$ with the cell temperatures and pressures at reference conditions for $\mathrm{P} 15$, from 50 to $85^{\circ} \mathrm{C}$ in $\mathrm{P} 25$ and from 50 to $90^{\circ} \mathrm{C}$ in P30.

Series 4 tests (Pt Series) were conducted on cells with different Pt loadings in the cathode. These cells were only operated at P15 reference operating conditions.

Series 5 tests (SRc Series) varied the $\mathrm{O}_{2}$ stoichiometry in P15, P25 and P30 tests from 1.5 to 5 with the inlet dew points adjusted to maintain $100 \% \mathrm{RH}$ at cell exit $\left(\mathrm{SR}_{\mathrm{a}}=2\right)$.

Series 6 tests (SRa Series) varied the $\mathrm{H}_{2}$ stoichiometry in P15, P25 and P30 tests from 1.2 to 5 with the dew points held at the reference values $\left(\mathrm{SR}_{\mathrm{c}}=2\right)$.

Series 7 tests (LT Series) were designed to investigate the cell operation during warm-up at 30, 45 , and $60^{\circ} \mathrm{C}$ with dry feeds at $\mathrm{P} 15$ and $\mathrm{P} 25$ operating pressures and at $30,45,60$ and $70^{\circ} \mathrm{C}$ at P30 operating pressures. 
Series 8 tests (ID Series) were designed to investigate cell operation during idling at low pressures and high $\mathrm{O}_{2}$ stoichiometries. The data were obtained only at P15 operating cell temperature and $100 \%$ inlet $\mathrm{RH}$.

As in earlier work [12], the polarization curves for the eight series of tests were obtained using

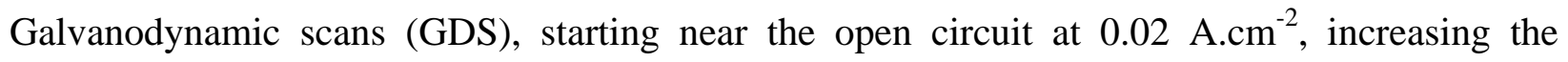
current density in steps until either $2 \mathrm{~A} \cdot \mathrm{cm}^{-2}$ was reached or the cell voltage decreased to $0.40 \mathrm{~V}$, followed by an upscan back to $0.02 \mathrm{~A} . \mathrm{cm}^{-2}$. The cell voltages were measured at ten current steps per decade but the maximum step size was limited to $0.1{\mathrm{~A} . \mathrm{cm}^{-2}}^{-2}$ The cell was held for $120 \mathrm{~s}$ at each current step and the cell voltage was recorded every $5 \mathrm{~s}$. Also, the cell resistance was determined every $5 \mathrm{~s}$ by on-line AC impedance measurements between 10 and $1 \mathrm{kHz}$, from which the high frequency resistance (HFR) was estimated by fitting to a Randle's cell model. The cell voltages reported in this are the measured values averaged over the last $30 \mathrm{~s}$ at the set current densities.

Prior to the start of the experiments, the electrochemical surface areas (ECSA) were determined by cyclic voltammetry (CV) between 0.085 and $0.65 \mathrm{~V}$ (vs. RHE) at $100 \mathrm{mV}^{-s^{-1}}$ scan rate, with $\mathrm{H}_{2} / \mathrm{N}_{2}$ at $70^{\circ} \mathrm{C}, 70^{\circ} \mathrm{C}$ dew points and ambient pressure. ECSA values were determined by averaging the oxidative and reductive $\mathrm{H}_{\mathrm{UPD}}$ peak areas from $100 \mathrm{CV}$ s and assuming a 210 $\mu \mathrm{C} . \mathrm{cm}-\mathrm{Pt}^{-2}$ charge-to-area conversion factor.

Hydrogen crossover current density and cell short resistance were determined by measuring the plateau currents between $0.4-0.6 \mathrm{~V}$ cell potentials with saturated $\mathrm{H}_{2} / \mathrm{N}_{2}$ at 1.5 atm total pressure and $80^{\circ} \mathrm{C}$ cell temperature.

The mass activities of $\mathrm{Pt}$ in each cell were measured in $\mathrm{H}_{2} / \mathrm{O}_{2}$ at $80^{\circ} \mathrm{C}$, 1-atm reactant $\mathrm{H}_{2}$ and $\mathrm{O}_{2}$ pressures and $100 \% \mathrm{RH}$. The measurement was made by first reducing the cathode with a 15- 
min hold under $\mathrm{H}_{2} / \mathrm{N}_{2}$ at $\sim 0.10 \mathrm{~V}$, switching the cathode to $\mathrm{O}_{2}$ and immediately holding the cathode potential at $0.90 \mathrm{~V}$ for 20 minutes. The mass activity values listed in Table 2 are the current densities, adjusted for $\mathrm{H}_{2}$ crossover and shorting currents, at a cell voltage of $0.9 \mathrm{~V}$ after 17.5 minutes.

\section{Theoretical}

The starting point of the analysis is to represent the cell voltage $(E)$ in terms of the Nernst potential $\left(E_{N}\right)$, Ohmic drop due to the high frequency resistance $\left(i R_{\Omega}\right)$, cathode activation overpotential for the oxygen reduction reaction $\left(\eta_{a}^{c}\right)$, mass transfer overpotential in cathode $\left(\eta_{m}^{c}\right)$, anode overpotential for the hydrogen oxidation reaction $\left(\eta_{a}^{a}\right)$, and mass transfer overpotential in anode $\left(\eta_{m}^{a}\right)$ as

$$
E=E_{N}-i R_{\Omega}-\eta_{a}^{c}-\eta_{m}^{c}-\eta_{a}^{a}-\eta_{m}^{a}
$$

$$
E_{N}=E_{0}+\frac{R T}{n F} \ln \left(\frac{P_{H_{2}}^{a}\left(P_{O_{2}}^{c}\right)^{1 / 2}}{\phi_{m}^{c}}\right)
$$

where $E_{0}$ is the standard potential for the fuel cell reaction assuming that the product water is liquid, $\phi_{m}^{c}$ is the relative humidity ( 1 for $100 \% \mathrm{RH}$ ) in the cathode catalyst layer (CCL), and $n$ equals 2 .

$E_{0}=1.23-0.000833(T-298)$

In Eq. (1a), $\mathrm{H}_{2}$ and $\mathrm{O}_{2}$ partial pressures are evaluated in the anode and cathode gas channels

Following Ref. [12], the overpotential for the oxygen reduction reaction (ORR) on $\mathrm{PtCoMn} / \mathrm{NSTF}$ catalyst is estimated from the following Tafel equation developed from the $\mathrm{H}_{2} /$ air polarization data at low current densities. 
$i+i_{x}=i_{0}^{c} A_{P t}^{c} L_{P t}^{c} P_{O_{2}}^{\gamma}\left(\phi_{m}^{c}\right)^{\beta} \exp \left(\frac{\alpha_{c}^{c} n F}{R T} \eta_{a}^{c}\right)$

$i_{0}^{c}=i_{0 r}^{c} \exp \left[-\frac{E_{O_{2}}}{R}\left(\frac{1}{T}-\frac{1}{T_{R}}\right)\right]$

where $i_{x}$ is the hydrogen cross-over current density. Table 2 lists the kinetic parameters for ORR kinetics on the ternary catalyst.

The overpotentials for the hydrogen oxidation reaction (HOR) on PtCoMn/NSTF catalyst are evaluated from the following Butler-Volmer equation [13] developed using data obtained in $\mathrm{H}_{2}$ pump tests.

$$
\begin{aligned}
& i=i_{0}^{a} A_{P t}^{a} L_{P t}^{a} P_{H_{2}}\left[\exp \left(\frac{\alpha_{a}^{a} n F}{R T} \eta_{a}^{a}\right)-\exp \left(-\frac{\alpha_{c}^{a} n F}{R T} \eta_{a}^{a}\right)\right] \\
& i_{0}^{a}=i_{0 r}^{a} \exp \left[-\frac{E_{H_{2}}}{R}\left(\frac{1}{T}-\frac{1}{T_{R}}\right)\right]
\end{aligned}
$$

Table 2 also includes the kinetic parameters for HOR on the ternary catalyst. The anode mass transfer overpotentials are small when the cell is operated with pure $\mathrm{H}_{2}$ as fuel and are neglected in this work.

\subsection{Cell Model}

A simple one-dimensional model was adopted for estimating the local values of $i, P_{\mathrm{O}_{2}}, P_{\mathrm{H}_{2}}$ and $\Phi$ in the counter-flowing anode (x direction) and cathode (-x direction) streams. The model solves the following set of equations for anode and cathode pressures and for molar flow rates $(\dot{N})$ of $\mathrm{H}_{2}, \mathrm{O}_{2}$ and $\mathrm{H}_{2} \mathrm{O}$ (subscript w) in the anode (superscript a) and cathode (superscript c) channels considering the source terms for the electrochemical reactions and water transport flux $\left(J_{w}^{m}\right)$ across the membrane (superscript $\mathrm{m}$ ) by electro-osmotic drag and diffusion (normal direction $\mathrm{y}$ ). 


$$
\begin{aligned}
& \frac{d P^{c}}{d x}=\frac{\Delta P^{c}}{L} \\
& \frac{d P^{a}}{d x}=-\frac{\Delta P^{a}}{L} \\
& \frac{d N_{O_{2}}}{d x}=\frac{i+i_{x}}{4 F} W_{m} \\
& \frac{d N_{w}^{c}}{d x}=-\left(\frac{i+i_{x}}{2 F}+J_{w}^{m}\right) W_{m} \\
& \frac{d N_{H_{2}}}{d x}=-\frac{i+i_{x}}{2 F} W_{m} \\
& \frac{d N_{w}^{a}}{d x}=-J_{w}^{m} W_{m}
\end{aligned}
$$

For expediency, the electro-osmotic drag coefficient $\left(n_{d}\right)$ and the water diffusion coefficient $\left(D_{\phi}, 10^{-10} \mathrm{~m}^{2} / \mathrm{s}\right)$ were taken as function of average water activities across membrane $\phi_{m}$, so that the following equation obtains for the water transport flux $J_{w}^{m}$ across the membrane.

$$
\begin{aligned}
& J_{w}^{m}=n_{d} \frac{i}{F}-\frac{D_{\phi}}{\delta_{m}} \frac{P_{s}\left(\phi_{m}^{c}-\phi_{m}^{a}\right)}{R T} \\
& n_{d}= \begin{cases}0.137+0.056 e^{-1.12 \phi_{\mathrm{m}}^{4}+14.26 \phi_{\mathrm{m}}^{3}+7.95 \phi_{\mathrm{m}}^{2}+4.94 \phi_{m}} & \phi_{m}<1 \\
1 & \phi_{m} \geq 1\end{cases} \\
& D_{\phi}= \begin{cases}0.28 \phi_{m}^{3}-0.12 \phi_{m}^{2}+0.33 \phi_{\mathrm{m}} & \phi_{m}<1 \\
0.5 & \phi_{m} \geq 1\end{cases}
\end{aligned}
$$

where $\delta_{\mathrm{m}}$ is the membrane thickness and $\lambda$ is the water uptake in the membrane. The profiles of water vapor mole fraction across the anode and cathode GDLs were calculated in terms of the mass transfer coefficients ( $h_{w}^{a}$ and $h_{w}^{c}$ ) that are related to the diffusivities. 


$$
\begin{aligned}
& J_{w}^{m}=h_{w}^{a} \frac{P_{s}\left(\phi^{a}-\phi_{m}^{a}\right)}{R T} \\
& h_{w}^{a}=\frac{D_{w}^{a}}{\delta_{d}^{a}}\left(\varepsilon_{d}^{a} \frac{T}{298}\right)^{1.5} \frac{1}{P^{a}} \\
& J_{w}^{m}+\frac{i+i_{x}}{2 F}=h_{w}^{c} \frac{P_{s}\left(\phi_{m}^{c}-\phi^{c}\right)}{R T} \\
& h_{w}^{c}=\frac{D_{w}^{c}}{\delta_{d}^{c}}\left(\varepsilon_{d}^{c} \frac{T}{298}\right)^{1.5} \frac{1}{P^{c}}
\end{aligned}
$$

In Eq. (7a), the diffusion coefficient of water vapor in $\mathrm{H}_{2}\left(D_{w}^{a}\right)$ at the reference conditions of 1 atm and $298 \mathrm{~K}$ is taken as $0.52 \times 10^{-4} \mathrm{~m}^{2} . \mathrm{s}^{-1}$. Similarly, the diffusion coefficient of water vapor in $\operatorname{air}\left(D_{w}^{c}\right)$ at the same reference pressure and temperature is taken as $0.256 \times 10^{-4} \mathrm{~m}^{2} \cdot \mathrm{s}^{-1}$.

Reference [12] should be consulted for more details concerning the relationships between partial pressures and molar flow rates, between relative humidity and water vapor mole fraction, and between partial pressure of water vapor and the saturation pressure $\left(P_{s}\right)$. Reference [12] also provides the functional dependence of $\lambda$ on $\phi$ and the empirical correlations for pressure drops in anode and cathode gas channels.

\subsection{Heat Transfer Model}

We determine the MEA temperature by combining the energy equations for the anode and cathode flows and assuming that the anode electrode, cathode electrode, membrane, and anode/cathode gas flows are isothermal. The equation is written compactly in terms of enthalpy $(H)$ that includes the heat of formation and the latent heat of condensation. The summation is performed over $i$ species that make up the anode and cathode gases and implicitly accounts for the heat of reaction for $\mathrm{H}_{2}+1 / 2 \mathrm{O}_{2}=\mathrm{H}_{2} \mathrm{O}$. 


$$
\frac{d}{d x}\left(\sum_{i}\left(\dot{N}_{i}^{c} M_{i} H_{i}^{c}\right)\right)-\frac{d}{d x}\left(\sum_{i}\left(\dot{N}_{i}^{a} M_{i} H_{i}^{a}\right)\right)=\dot{Q}_{w} W_{m}+i E W_{m}
$$

We determine the coolant temperature profile by considering the heat transfer between the coolant and the MEA.

$$
\begin{aligned}
& \dot{m}_{w} C_{p w} \frac{d T_{w}}{d x}=\dot{Q}_{w} W_{m} \\
& \dot{Q}_{w}=U\left(T-T_{w}\right)
\end{aligned}
$$

\subsection{Cathode Mass Transfer Overpotential Model}

For applicability to hotter and drier conditions, we analyzed the available polarization data to develop a rational model for mass transfer overpotentials in ternary PtCoMn/NSTF catalysts. The approach was to first define a limiting current density $\left(i_{L}\right)$ at which the mass transfer overpotential equals a set value of $0.3 \mathrm{~V}$. This limiting current density was determined from the cell polarization data and was correlated as a function of the operating pressure $(\mathrm{P})$, temperature (T), oxygen mole fraction $\left(\mathrm{X}_{\mathrm{O}_{2}}\right)$, relative humidity $(\phi)$ and catalyst surface area $\left(A_{P t}^{c} L_{P t}^{c}\right)$. An elaborate procedure was formulated to extract the local value of $i_{L}$ from the polarization data with finite stoichiometry and varying $\mathrm{P}, \mathrm{X}_{\mathrm{O}_{2}}, \phi, L_{P t}^{c}$ and current density.

$$
\begin{aligned}
& i_{L}=i_{L}^{r}(P) f_{X} f_{T} f_{\phi} f_{C} \\
& i_{L}^{r}(P)=0.2767+0.5228 \mathrm{P}-0.0165 \mathrm{P}^{2} \\
& f_{X}=20 \mathrm{X}_{\mathrm{O}_{2}}-40 \mathrm{X}_{\mathrm{O}_{2}}^{2} \\
& f_{T}=1.224 \times 10^{-4}\left(\mathrm{~T}-\mathrm{T}_{\mathrm{r}}\right)^{3}-8.3102 \times 10^{-4}\left(\mathrm{~T}-\mathrm{T}_{\mathrm{r}}\right)^{2}+6.7383 \times 10^{-4}\left(\mathrm{~T}-\mathrm{T}_{\mathrm{r}}\right)+1 \\
& T_{r}= \begin{cases}353 K & P=1.5 \mathrm{~atm} \\
358 K & P=2.5 \mathrm{~atm} \\
363 K & P=3.0 \mathrm{~atm}\end{cases}
\end{aligned}
$$


$f_{\phi}= \begin{cases}-0.352\left(\phi_{\mathrm{m}}^{\mathrm{c}}\right)^{3}+0.427\left(\phi_{\mathrm{m}}^{\mathrm{c}}\right)^{2}+1.012 \phi_{\mathrm{m}}^{\mathrm{c}}-0.007 & \mathrm{P}=1.5 \mathrm{~atm} \\ 1.366\left(\phi_{\mathrm{m}}^{\mathrm{c}}\right)^{4}+4.121\left(\phi_{\mathrm{m}}^{\mathrm{c}}\right)^{3}-3.713\left(\phi_{\mathrm{m}}^{\mathrm{c}}\right)^{2}+1.771 \phi_{\mathrm{m}}^{\mathrm{c}}-0.058 & \mathrm{P}=2.5 \mathrm{~atm} \\ -0.053\left(\phi_{\mathrm{m}}^{\mathrm{c}}\right)^{3}-0.296\left(\phi_{\mathrm{m}}^{\mathrm{c}}\right)^{2}+1.162 \phi_{\mathrm{m}}^{\mathrm{c}}+0.053 & \mathrm{P}=3.0 \mathrm{~atm}\end{cases}$

$f_{C}=0.0151 A_{P t}^{c} L_{P t}^{c}+0.8475$

The second step was to correlate the mass transfer overpotential $\left(\eta_{m}^{c}\right)$ in terms of the reduced current density $\left(i / i_{L}\right)$, i.e., the current density $(i)$ normalized by $i_{L}$. As above, an elaborate procedure was formulated to extract the local value of $\eta_{m}^{c}$ from the polarization data with finite stoichiometry and varying $\mathrm{P}, \mathrm{X}_{\mathrm{O}_{2}}, \mathrm{~T}, \phi$ and $i / i_{L}$. Higher order terms were included in the $\eta_{m}^{c}$ correlation to correct for $\mathrm{T}, \mathrm{RH}$, and cathode stoichiometry $(\psi)$.

$$
\begin{aligned}
& \eta_{m}^{c}=0.3\left(i / i_{L}\right)^{1 / 2} e^{-g_{P} g_{T} g_{\phi} g_{\psi}\left(1-i / i_{L}\right)} \\
& g_{P}=4.116 \\
& g_{T}=228.704\left(\mathrm{~T} / \mathrm{T}_{\mathrm{r}}\right)^{3}-623.6916\left(\mathrm{~T} / \mathrm{T}_{\mathrm{r}}\right)^{2}+567.5707\left(\mathrm{~T} / \mathrm{T}_{\mathrm{r}}\right)-171.594 \\
& g_{\phi}= \begin{cases}1.269\left(\phi_{\mathrm{m}}^{\mathrm{c}}\right)^{3}-4.799\left(\phi_{\mathrm{m}}^{\mathrm{c}}\right)^{2}+4.755 \phi_{\mathrm{m}}^{\mathrm{c}}-0.043 & \mathrm{P}=1.5 \mathrm{~atm} \\
0.799\left(\phi_{\mathrm{m}}^{\mathrm{c}}\right)^{3}-2.804\left(\phi_{\mathrm{m}}^{\mathrm{c}}\right)^{2}+2.482 \phi_{\mathrm{m}}^{\mathrm{c}}+0.671 & \mathrm{P}=2.5 \mathrm{~atm} \\
0.659\left(\phi_{\mathrm{m}}^{\mathrm{c}}\right)^{3}-2.655\left(\phi_{\mathrm{m}}^{\mathrm{c}}\right)^{2}+2.971 \phi_{\mathrm{m}}^{\mathrm{c}}+0.277 & \mathrm{P}=3.0 \mathrm{~atm}\end{cases} \\
& g_{\psi}=-0.646 \psi^{2}+2.804 \psi-2.027
\end{aligned}
$$

The above correlations for $i_{L}$ and $\eta_{m}^{c}$ are valid over the following range of variables: $1<\mathrm{P}<3$ atm, $65<\mathrm{T}<95^{\circ} \mathrm{C}, 0.05<\mathrm{X}_{\mathrm{O}_{2}}<0.2,0.3<\phi_{\mathrm{m}}^{\mathrm{c}}<1.9,1.5<\psi<5$, and $0.05<<0.15 \mathrm{mg}-\mathrm{Pt} . \mathrm{cm}^{-2}$.

\section{Model Validation}

Figures 1a shows the increase in local limiting current density $\left(i_{L}\right)$ with increase in $\mathrm{O}_{2}$ mole fraction at operating pressures as calculated from Eq. (11) at $80^{\circ} \mathrm{C}$ and $100 \% \mathrm{RH}$ at membrane- 
cathode interface $\left(\phi_{\mathrm{m}}^{\mathrm{c}}\right)$. As a reference, $\mathrm{O}_{2}$ mole fraction is $21 \%$ in dry air, and it decreases to $\sim 7 \%$ at exit of stack operating at $\mathrm{SR}_{\mathrm{c}}=2,1.5 \mathrm{~atm}, 80^{\circ} \mathrm{C}$ and $100 \% \mathrm{RH}$. Figure $1 \mathrm{~b}$ quantifies the corresponding decrease in local mass transfer overpotentials $\left(\eta_{m}^{c}\right)$ with increase in operating pressure at different current densities; we used Eq. (12) to calculate $\eta_{m}^{c}$ for a cathode stoichiometry of 2 and $\mathrm{O}_{2}$ mole fraction averaged over the cell inlet and exit values. Figure 1c compares the modeled polarization curves with experimental data for tests at different operating pressures, $80^{\circ} \mathrm{C}, \mathrm{SR}_{\mathrm{a}}=\mathrm{SR}_{\mathrm{c}}=2$, and $100 \% \mathrm{RH}$ at cell exit. For this comparison, the model results were obtained by integrating Eqs. (4), (5), (9) and (10) using 20 nodes along the flow direction, with proper accounting of counter-flowing anode and cathode streams. We also used Eq. (2) for ORR kinetics, Eq. (3) for HOR kinetics, and Eqs. (11) - (12) for mass transfer overpotentials.

As further validation, we similarly present the effect of temperature on local limiting current density in Fig. 1d, local mass transfer overpotential in Fig. 1e, and polarization curves in Fig. If at $100 \%$ exit $\mathrm{RH}, 2.5 \mathrm{~atm}$ operating pressure and $\mathrm{SRc}=2$. Under these conditions, Fig. 1e indicates that the mass transfer overpotentials are small, $<10 \mathrm{mV}$, at current densities below 1.5 A.cm ${ }^{-2}$. The small differences in isothermal cell performance in Fig. 1f at different temperatures are due to other direct and indirect effects of temperature on membrane resistance $\left(R_{\Omega}\right)$, ORR kinetic overpotentials $\left(\eta_{a}^{c}\right)$ and $\mathrm{P}\left(\mathrm{O}_{2}\right)$. Relative to the polarization curve at $85^{\circ} \mathrm{C}$, the high current density performance is worse at $75^{\circ} \mathrm{C}$ because of greater mass transfer overpotentials and is slightly worse at $90^{\circ} \mathrm{C}$ because of smaller $\mathrm{P}\left(\mathrm{O}_{2}\right)$. Overall, the modeled effect of temperature on polarization curves at $2.5 \mathrm{~atm}$ is in good agreement with the experimental data. 
For brevity, we have not shown the equally good comparisons between the modeled and measured polarization curves for other series of tests with RH, anode/cathode stoichiometries, cathode Pt loadings as variables and different combinations of P, T, RH and stoichiometries.

\section{Results and Discussion}

The cell model was used to analyze the performance of an $80-\mathrm{kW}_{\text {net }}$ reference fuel cell system (see the figure included in Table 3) with ternary PtCoMn/NSTF catalysts in the PEFC stack. The details of the system configuration are discussed in Refs. [14, 15] and will not be repeated here. Table 3 lists the important performance parameters of the components comprising the stack, fuel management system, air management system with a compressor-expander module (CEM), heat rejection system and water management system. In applying the model developed from a single $50-\mathrm{cm}^{2}$ cell to a large stack with $>250 \mathrm{~cm}^{2}$ active membrane area and $>300$ cells, we assumed a $10 \mathrm{mV}$ cell-to-stack voltage degradation $\left(\Delta \mathrm{V}_{\mathrm{cs}}\right)$ at $1 \mathrm{~A} . \mathrm{cm}^{-2}$ current density. This allowance, amounting to $10 \mathrm{~m} \Omega \cdot \mathrm{cm}^{2}$ additional resistance, accounts for possible electrical losses due to channel-to-channel and cell-to-cell flow non-uniformities in large stacks. Also, whereas, the model has been developed by using data for isothermal cells, it can be applied to non-isothermal cells since it is based on local temperature, taken as the bipolar plate temperature which can be calculated from the local coolant temperature, coolant flow rate and heat transfer to the coolant.

Most of the results presented below are based on an optimization study that minimizes the fuel cell system cost subject to multiple constrains including $\mathrm{Q} / \Delta \mathrm{T}$ of $1.45 \mathrm{~kW} /{ }^{\circ} \mathrm{C}$. In this study, we use the cost correlations developed by James et al [16] for the subsystems in Table 3 at high volume manufacturing, 500,000 units/year, and 1500 \$/tr-oz. price of Pt. Table 4 lists the correlations for the cost of the various subsystems as a function of the important parameters: active membrane area, Pt loading and Pt price for stack with metal bipolar plates and NSTF 
electrocatalyst; pressure and air flow rate for the air management system with high-speed centrifugal compressor and expander; heat loads and temperature difference for the thermal management system; humidifier membrane area and pre-cooler heat load and temperature differential for the thermal management system; and the operating pressure for the fuel management system. The constants and coefficients account for the costs of all components (e.g., GDLs, bipolar plates, end plates, demister, ejector, balance-of-plant, etc.) for which the costs do not explicitly appear in the correlations.

Figure 2 presents illustrative results from an initial parametric study on the dependence of stack and water management system costs on the coolant exit temperature. The results are for specified Pt loading in anode and cathode $\left(0.05 / 0.1 \mathrm{mg} \cdot \mathrm{cm}^{-2}\right)$, stack inlet pressure $(2.5 \mathrm{~atm})$, rise in coolant temperature $\left(10^{\circ} \mathrm{C}\right)$, ambient temperature $\left(40^{\circ} \mathrm{C}\right)$, and anode/cathode stoichiometries $(2 / 2)$. Two sets of results are included in Fig. 2: one in which the exit cathode RH is restricted to 100\%, and the other in which it is optimized for minimum FCS cost. For fixed $\mathrm{Q} / \Delta \mathrm{T}$, raising the coolant temperature results in higher $\Delta \mathrm{T}$, higher allowable $\mathrm{Q}$, and, therefore lower cell voltage. The stack cost decreases sharply because of higher stack power density at lower cell voltages. However, raising the exit coolant temperature from 85 to $95^{\circ} \mathrm{C}$ for $100 \%$ exit $\mathrm{RH}$ leads to more than 10 fold increase in humidifier membrane area $\left(<0.4\right.$ to $\left.4.7 \mathrm{~m}^{2}\right)$, so that there is an optimum coolant temperature $\left(\sim 91^{\circ} \mathrm{C}\right)$ for which the system cost is the lowest. Without the $100 \%$ exit $\mathrm{RH}$ restriction, the stack cost decreases even faster upon raising $T_{c}$ while the increase in humidifier cost is slower [17], so that the minimum system cost is at the highest coolant temperature considered in this study. For the parameters of this study, the optimum RH at stack outlet decreases from $97.5 \%$ to $\sim 80 \%$ as $T_{c}$ is raised from $85^{\circ} \mathrm{C}$ to $95^{\circ} \mathrm{C}$. 


\subsection{Optimization Study with $\mathrm{Q} / \Delta \mathrm{T}$ Constraint}

A multi-variable optimization study was conducted to determine the combination of coolant temperature, relative humidity at stack exit and the cell voltage for minimum system cost, subject to $1.45 \mathrm{~kW} /{ }^{\circ} \mathrm{C} \mathrm{Q} / \Delta \mathrm{T}$ constraint for specified Pt loading in anode/cathode catalysts and $10^{\circ} \mathrm{C}$ rise in coolant temperature. The cathode stoichiometry and stack inlet pressure were treated as study parameters. The results from the study are summarized in Figs. 3-6.

Figure 3 summarizes the dependence of the optimum coolant exit temperature and the cell voltage on cathode stoichiometry and the stack inlet pressure for $100 \%$ exit RH. For fixed RH at stack exit, raising the cathode stoichiometry or lowering the inlet pressure increases the required water transport in the cathode humidifier. Since the humidification load is also a strong function of temperature, Fig. 3a shows that the optimum coolant exit temperature for minimum system cost must decrease under these conditions. The results in Fig. $3 \mathrm{~b}$ indicate that with the $\mathrm{Q} / \Delta \mathrm{T}$ constraint, the cell voltage at the optimum coolant exit temperature has to increase to compensate for the additional CEM power at higher cathode stoichiometry. We conclude that low stack inlet pressures $(1.5 \mathrm{~atm})$ may not be acceptable because the optimum coolant exit temperature is restricted to $<81^{\circ} \mathrm{C}, \Delta \mathrm{T}$ to $<41^{\circ} \mathrm{C}$ and $\mathrm{Q}$ to $<60 \mathrm{~kW}$, so that the required cell voltage has to be $>760 \mathrm{mV}$. Also, the cathode stoichiometry needs to be $<2$ to keep the cell voltage below $700 \mathrm{mV}$ at 2.5 atm stack inlet pressure.

The results indicate that, over the range of cathode stoichiometries $\left(\mathrm{SR}_{\mathrm{c}}\right)$ and stack inlet pressures investigated in this study, the required cell voltage and the system cost $\left(\$ / \mathrm{kW}_{\mathrm{e}}\right)$ are lowest at $\mathrm{SR}_{\mathrm{c}}=1.5$. Therefore, only the results for $\mathrm{SR}_{\mathrm{c}}=1.5$ are included in Figs. 4-6.

Consistent with the results in Fig. 2, Figs. 4a and $4 \mathrm{~b}$ show that the differences in system cost and Pt content $\left(\mathrm{g} / \mathrm{kW}_{\mathrm{e}}\right)$ between saturated $\left(\mathrm{RH}_{\mathrm{c}}=100 \%\right)$ and un-saturated $\left(\mathrm{RH}_{\mathrm{c}}<=100 \%\right)$ cathode 
exits are large at low operating pressures and diminish at high operating pressures. The optimum cathode exit RH is $>86 \%$ if the stack inlet pressure is higher than 2.5 atm and it is $<73 \%$ if the inlet pressure is $1.5 \mathrm{~atm}$. At the optimum conditions, both the exit anode and cathode streams are slightly supersaturated (RH > 100\%) at 3 atm stack inlet pressure.

The relative humidity affects the system cost and performance at many levels. It determines the size and cost of the humidifier because the required water vapor transport (WVT) is directly proportional to RH for given pressure and temperature. For specified RH and temperature, WVT in the humidifier is inversely proportional to pressure. Whereas, raising the RH improves the membrane conductivity (smaller Ohmic resistance), it decreases the Nernst potential because of lower $\mathrm{P}\left(\mathrm{H}_{2}\right)$ and $\mathrm{P}\left(\mathrm{O}_{2}\right)$ and higher $\mathrm{P}\left(\mathrm{H}_{2} \mathrm{O}\right)$. More importantly, the resultant drop in oxygen concentration at higher $\mathrm{RH}$ leads to much larger kinetic and mass transfer overpotentials, especially at low pressures.

The system cost in Fig. 4a is lowest at 3-atm stack inlet pressure, but the cost saving is small compared to 2.5-atm inlet pressure. Although the stack has to generate additional power to compensate for the greater CEM parasitic power as the inlet pressure is raised, the system cost and Pt content are lower. Figure 4a clearly indicates that, for 100\% RH at cathode exit, stack inlet pressures below 2 atm are unacceptable from the standpoints of system cost (>90 $\$ / \mathrm{kW}_{\mathrm{e}}$ ) and system performance $\left(>0.6 \mathrm{~g}-\mathrm{Pt} / \mathrm{kW}_{\mathrm{e}}\right)$.

Figure $4 \mathrm{c}$ shows that the cell voltage required to meet the $\mathrm{Q} / \Delta \mathrm{T}$ constraint at $1.5 \mathrm{~atm}$ stack inlet pressure is $94 \mathrm{mV}$ lower if the stack is operated hotter $\left(92^{\circ} \mathrm{C}\right.$ vs. $\left.82^{\circ} \mathrm{C}\right)$ and drier $(73 \% \mathrm{RH}$ vs. $100 \% \mathrm{RH})$. The required cell voltage with exit $\mathrm{RH}$ restricted to $100 \%$ decreases sharply as the stack inlet pressure is raised from $1.5 \mathrm{~atm}$ to $3 \mathrm{~atm}$. Without the $100 \% \mathrm{RH}$ restriction, the required cell voltage decreases by $\sim 20 \mathrm{mV}$ as the stack inlet pressure is raised from 1.5 to 2 atm, 
and then increases as the inlet pressure is raised to 3 atm because of the increase in power consumed by the CEM. The stack power density in Fig. $4 \mathrm{~d}$ is $<500 \mathrm{~mW} . \mathrm{cm}^{-2}$ for stack operating pressures below 2.2 atm for $100 \%$ exit $\mathrm{RH}$ and 1.7 atm for unrestricted $\mathrm{RH}$. The difference in power densities for restricted and unrestricted RH diminishes as the stack inlet pressure is raised above 2.5 atm since, even without the $\mathrm{RH}$ restriction, the optimum cathode exit $\mathrm{RH}$ approaches and exceeds $100 \%$ at 3 atm stack inlet pressure.

Figure 4e presents the system efficiency on a lower heating value (LHV) basis that the FCS must have in order to meet the $\mathrm{Q} / \Delta \mathrm{T}$ constraint at rated power. Imposing the heat rejection constraint makes the system efficiency at rated power a function of the operating pressure. The required efficiency is lower (desired result) at higher stack inlet pressures or if the cathode exit RH is less than $100 \%$ (although there are durability implications). Note that the anode outlet may contain condensed water; the stack heat load in Fig. $4 \mathrm{f}$ includes this latent heat and the sensible heat loads due to rise in gas temperatures in addition to the waste heat generated (related to cell voltage) by the thermodynamic irreversibilities in the cell electrochemical reactions (i.e., cell overpotentials). With the maximum coolant temperature limited to $95^{\circ} \mathrm{C}$ (study assumption), the allowable stack heat load corresponding to $1.45 \mathrm{~kW} /{ }^{\circ} \mathrm{C} \mathrm{Q} / \Delta \mathrm{T}$ in Fig. $4 \mathrm{f}$ is restricted to $79.8 \mathrm{~kW}$.

\subsection{Optimum Pt Loading}

A parametric study was conducted to determine the optimum Pt loading in the cathode catalyst for $\mathrm{SR}_{\mathrm{c}}=1.5$. Figure 5a shows that the cathode with the smallest Pt loading considered in this study $\left(0.054 \mathrm{mg} . \mathrm{cm}^{-2}\right)$ has the lowest Pt content but also the lowest power density (see Table 5 for 2.5 atm stack inlet pressure). Table 5 indicates that the cost of the balance-of-stack (BOS) components (membrane, bipolar plate, GDL) decreases from $65 \%$ to $46 \%$ as the cathode Pt loading is increased from 0.054 to $0.146 \mathrm{mg} / \mathrm{cm}^{2}$ and the power density improves from 565 to 
$690 \mathrm{~mW} / \mathrm{cm}^{2}$. Increasing the Pt loading above $0.15 \mathrm{mg} / \mathrm{cm}^{2}$ does not result in higher power density, suggesting that there may be a room to further optimize the electrode structure (e.g., adjusting whisker density, diameter and aspect ratio) for cathodes with such high Pt loadings. Figure $5 \mathrm{~b}$ shows that the lower BOS cost nearly offsets the higher Pt cost so that there is less than $2 \%$ change in system cost as the Pt loading is increased from 0.054 to $0.103 \mathrm{mg} / \mathrm{cm}^{2}$. Since low-Pt cathodes are known to have issues with durability and tolerance to contaminants, considering cost and durability, $0.103 \mathrm{mg} / \mathrm{cm}^{2}$ is likely the optimum Pt loading for the ternary NSTF catalyst.

It is worth mentioning that the market price of Pt has fluctuated between $\$ 1100$ and $\$ 1500$ per troz. The optimum Pt loading in cathode would be higher than $0.103 \mathrm{mg} / \mathrm{cm}^{2}$ if the Pt price is $\$ 1100 /$ tr-oz rather than $\$ 1500 /$ tr-oz assumed in this study.

\subsection{Q $/ \Delta \mathrm{T}$ Constraint}

In our study, $\mathrm{Q}$ is the actual stack heat load (AQ) as calculated in the model considering variable $\mathrm{P}\left(\mathrm{O}_{2}\right), \mathrm{P}\left(\mathrm{H}_{2}\right), \mathrm{P}\left(\mathrm{H}_{2} \mathrm{O}\right), \mathrm{T}$, and current density along the flow directions. The model includes latent heat released by water condensation (if any) in the stack and the sensible heat transfer to the anode and cathode gases. Besides the cell voltage, AQ should depend on operating conditions such as the operating pressure, temperature, and anode/cathode stoichiometry, and rise in coolant temperature. The heat load in the $\mathrm{Q} / \Delta \mathrm{T}$ target $(\mathrm{SN})$ is written in terms of voltage efficiency $\left(\eta_{V}=E / E_{N}\right)$, defined as the ratio of cell voltage to the Nernst potential $\left(E_{N}\right)$.

$Q=P_{\mathrm{s}}\left(\frac{1}{\eta_{V}}-1\right)=P_{s} \frac{\left(E_{N}-E\right)}{E}$ 
where $P_{\mathrm{s}}$ is the stack gross power required for a fuel cell system that generates $80 \mathrm{~kW}$ net power; the suggested value of $P_{\mathrm{s}}$ is $90 \mathrm{~kW}$. The target also suggests that, for simplicity, $E_{N}$ be approximated as $1.25 \mathrm{~V}$, independent of the stack operating conditions.

Figure 6 summarizes results from a study to investigate the effect of stack heat load estimates (AQ vs. SN) on the cost and performance of the reference system at different operating pressures. Both sets of results, labeled as $\mathrm{Q} / \Delta \mathrm{T}(\mathrm{AQ})$ and $\mathrm{Q} / \Delta \mathrm{T}(\mathrm{SN})$, are for optimized $\mathrm{T}_{\mathrm{c}}$ and RH with specified stack inlet pressure (1.5-3 atm), cathode stoichiometry (1.5), rise in coolant temperature $\left(10^{\circ} \mathrm{C}\right)$, and Pt loading in anode and cathode. The results show that, under most conditions, $\mathrm{Q}(\mathrm{SN})$ is an acceptable approximation to the actual stack heat load. $\mathrm{Q}(\mathrm{SN})$ grossly underestimates the heat load for conditions under which liquid water forms in the stack and significant amount of the latent heat of condensation is released, as at 3-atm stack inlet pressure.

\subsection{Data Variability}

As discussed in Section 2, an extensive data base was developed by running more than 130 polarization and electrochemical characterization tests on multiple cells. The reference conditions at $1.5(\mathrm{P} 15), 2.5(\mathrm{P} 25)$ and 3 atm (P30) were visited many times during different test series. Figure 7 a shows the variability in polarization curves at 2.5 -atm reference pressure in two of the eight cells (23102 and 23272); similar variations were also observed at $1.5 \mathrm{~atm}$ and 3 atm reference pressures. The inset in Fig. 7a identifies the test series in which the data were taken and the order in which the tests were conducted: Series $5(\mathrm{SRc}), 6(\mathrm{SRa}), 1(\mathrm{~T})$ and $3(\mathrm{RH})$ for cell 23102, and Series 1, 5, 6 and 3 for cell 23272. Figure $7 \mathrm{~b}$ indicates that the variability in cell voltage $(\Delta \mathrm{V})$ is a function of the current density and is higher at higher current density. We may regard $\Delta \mathrm{V}$ as a measure of the recoverable losses since the test campaign is not long enough for manifestation of significant irrecoverable losses. In a different study, we confirmed that the 
voltage losses in Fig. 7a can be recovered by reconditioning the cells by subjecting them to multiple thermal conditioning (TC) cycles. Nevertheless, the variability in cell voltage is representative of the performance variation that may be expected over drive cycles before the onset of permanent degradation mechanisms. The variability may be attributed to the accumulation of impurities and the initial state of the membrane at the start of a test series. The test data are likely to be more reproducible if, prior to taking polarization data, the cell is subjected to a standardized break-in and oxide-reduction protocol such as the one recommended in Ref. [2].

The model discussed in this paper is representative (REP) of the average performance in that the kinetic and transport parameters were determined by using the average of all available polarization data. We also developed a model for the best-of-class (BOC) performance in which we determined the kinetic and transport parameters using the only best polarization data under different conditions. Figures 7c and 7d compare the FCS cost and performance using the REP

and BOC models. Table 6 shows $\sim 10 \%$ improvement in power density $\left(753 \mathrm{~mW} / \mathrm{cm}^{2}\right)$, Pt cost $\left(10.8 \mathrm{~kW}_{\mathrm{e}}\right)$ and stack cost $\left(25.7 \$ / \mathrm{kW}_{\mathrm{e}}\right)$ if the results for 2.5 atm stack inlet pressure are based on BOC rather than REP polarization data.

\subsection{Impact of $Q / \Delta T$ Constraint}

We conducted a systematic study to evaluate the impact of $\Delta \mathrm{V}_{\mathrm{sc}}$ and $\mathrm{Q} / \Delta \mathrm{T}$ constraint on cost and performance projections. We used the BOC model for this study because many of the cell polarization data reported in literature are equivalent to the BOC rather REP data.

Figure 8a presents stack power density at three different cell voltages needed to satisfy the $\mathrm{Q} / \Delta \mathrm{T}$ (SN) constraint at cathode stoichiometries of 2.5, 2 and 1.5, 2.5 atm stack inlet pressure, and $95^{\circ} \mathrm{C}$ coolant exit temperature. The Pt loadings, $\Delta \mathrm{T}_{\mathrm{c}}$ and anode stoichiometries are the same as in 
Fig. 4. The required cell voltage is progressively higher as $\mathrm{SR}_{\mathrm{c}}$ is raised because, for fixed 80$\mathrm{kW}_{\mathrm{e}}$ net system power, the stack has to produce additional power to compensate for the higher CEM parasitic losses at higher air flow rates. So to maintain the same $\mathrm{Q}(\mathrm{Q} / \Delta \mathrm{T}$ fixed at 1.45 $\mathrm{kW} /{ }^{\circ} \mathrm{C}$ ), the cell voltage has to increase for higher efficiency. For this reason, in spite of higher $\mathrm{P}\left(\mathrm{O}_{2}\right)$, the power density in Fig. $8 \mathrm{a}$ is smaller at $\mathrm{SR}_{\mathrm{c}}=2.5$ than at $\mathrm{SR}_{\mathrm{c}}=2$.

The leftmost cluster in Fig. 8a indicates that the modeled BOC power densities can reach 880$964 \mathrm{~mW} / \mathrm{cm}^{2}$ at $85^{\circ} \mathrm{C}$ and $100 \%$ exit RH at the cell level $\left(\Delta \mathrm{V}_{\mathrm{sc}}=0\right)$. These values are comparable to the BOC power densities measured in isothermal cell tests under similar conditions. Introducing $10 \mathrm{mV}$ cell-to-stack voltage loss (cluster 2) results in 9.0-9.2\% reduction in the stack power density. Raising the exit coolant temperature to $90^{\circ} \mathrm{C}$ (cluster 3) causes $10-26 \mathrm{~mW} / \mathrm{cm}^{2}$ (1.2-3.1\%) reduction in power density. Further raising the coolant temperature to $95^{\circ} \mathrm{C}$ (cluster 4) to meet the $\mathrm{Q} / \Delta \mathrm{T}$ constraint results in an additional $\sim 40 \mathrm{~mW} / \mathrm{cm}^{2}(4.5-5.0 \%)$ reduction in power density. Finally, relaxing the $100 \%$ exit RH constraint for minimum system cost further reduces the power density by $7-30 \mathrm{~mW} / \mathrm{cm}^{2}(0.9-3.9 \%)$.

Figure $8 \mathrm{~b}$ presents the variation in FCS cost on introducing the $10 \mathrm{mV}$ cell-to-stack voltage loss and as the coolant exit temperature is raised from 85 to $95^{\circ} \mathrm{C}$ and the $100 \%$ exit $\mathrm{RH}$ constraint is relaxed. Introducing $10 \mathrm{mV}$ cell-to-stack voltage loss (cluster 2) results in 1.5-2 $\$ / \mathrm{kW}_{\mathrm{e}}$ increase in FCS cost. Raising the exit coolant temperature to $90^{\circ} \mathrm{C}$ (cluster 3) increases the costs of PEFC stack (lower power density) and water management system (higher WVT requirement) but reduces the costs of the thermal management system; the overall FCS cost increases by 2.1 $\$ / \mathrm{kW}_{\mathrm{e}}$ for $\mathrm{SR}_{\mathrm{c}}=2.5$ and by $0.7 \$ / \mathrm{kW}_{\mathrm{e}}$ for $\mathrm{SR}_{\mathrm{c}}=2$, but slightly decreases by $0.3 \$ / \mathrm{kW}_{\mathrm{e}}$ for $\mathrm{SRc}=$ 1.5. Further raising the coolant temperature to $95^{\circ} \mathrm{C}$ (cluster 4) results in an additional 1.5-5.9 $\$ / \mathrm{kW}_{\mathrm{e}}$ increase in FCS cost. Finally, relaxing the $100 \%$ exit RH constraint reduces the FCS cost 
by $0.5-5.5 \$ / \mathrm{kW}_{\mathrm{e}}$ because of saving in the costs of the water management system. The last cluster shows that the FCS cost is lowest for $\mathrm{SR}_{\mathrm{c}}=1.5$ although the stack power density is highest in Fig. $8 \mathrm{a}$ for $\mathrm{SR}_{\mathrm{c}}=2$.

Figure $8 \mathrm{c}$ presents the breakdown of the costs for conditions needed to satisfy the $\mathrm{Q} / \Delta \mathrm{T}$ constraint at minimum cost (cluster 5 in Figs. $8 \mathrm{a}$ and $8 \mathrm{~b}$ ). The stack cost is lowest for $\mathrm{SR}_{\mathrm{c}}=2$, but the air, thermal and water management subsystems have the lowest cost for $\mathrm{SR}_{\mathrm{c}}=1.5$. The air management system contributes significantly to the overall system cost; the projected cost of the air system is $45-55 \%$ of the stack cost.

\section{Summary and Conclusions}

We have investigated the impact of the heat rejection $(\mathrm{Q} / \Delta \mathrm{T})$ constraint on the design, performance and cost of automotive fuel cell systems for propulsion of light duty vehicles. The combined experimental and theoretical work was conducted on MEAs with nanostructured thin film (NSTF), ternary PtCoMn electrocatalysts and low Pt loadings in the cathode $(<0.20 \mathrm{mg}$ $\mathrm{Pt} / \mathrm{cm}^{2}$ ). The validated cell model was used in a reference PEFC system with all the relevant balance-of-plant (BOP) components to analyze the cost and performance of automotive systems subject to the $\mathrm{Q} / \Delta \mathrm{T}$ constraint. The main conclusions from this investigation are highlighted below.

- Meeting the $\mathrm{Q} / \Delta \mathrm{T}$ constraint requires that the stack be operated hotter (coolant exit temperature $>90^{\circ} \mathrm{C}$ ), drier (stack exit $\mathrm{RH}<100 \%$ ) and at elevated pressures (inlet pressures $>2 \mathrm{~atm})$.

- Low stack inlet pressures (1.5 atm) and 100\% cathode exit RH may not be acceptable because the coolant exit temperature is restricted to $<82^{\circ} \mathrm{C}$, and the required cell voltage has to be $>760 \mathrm{mV}$, resulting in a power density $<160 \mathrm{~mW} / \mathrm{cm}^{2}$. 
- The cathode stoichiometry needs to be less than 2 to keep the cell voltage below $700 \mathrm{mV}$ at 2.5 atm stack inlet pressure. Within the range of stoichiometries investigated in this study, $\mathrm{SR}_{\mathrm{c}}=1.5$ yields acceptable performance (i.e., low Pt content) at least cost.

- The optimum cathode exit RH is $>86 \%$ if the stack inlet pressure is higher than 2.5 atm and it is $<73 \%$ if the inlet pressure is $1.5 \mathrm{~atm}$.

- The optimum Pt loading in the cathode ternary catalyst is between 0.1 and $0.125 \mathrm{mg} \cdot \mathrm{cm}^{-2}$ although the Pt content is reduced at lower Pt loading $\left(0.054 \mathrm{mg} . \mathrm{cm}^{-2}\right)$ and the power density is higher at higher Pt loading $\left(0.146 \mathrm{mg} \cdot \mathrm{cm}^{-2}\right)$.

- For the conditions of this study, the projected Pt content and cost of an optimized 80-kWe fuel cell system that meets the $1.45 \mathrm{~kW} /{ }^{\circ} \mathrm{C}$ constraint are $0.25 \mathrm{~g} / \mathrm{kW}_{\mathrm{e}}$ and $56.2 \$ / \mathrm{kW}_{\mathrm{e}}$. The performance and cost improve by $\sim 10 \%$ if the projections are based on the best-of-class data rather than the representative data.

- Figure 8 illustrates the cascading manner in which imposing the heat rejection constraint and introducing $10 \mathrm{mV}$ cell-to-stack voltage degradation results in the BOC power density decreasing from $964 \mathrm{~mW} \cdot \mathrm{cm}^{-2}$ at $673 \mathrm{mV}, 85^{\circ} \mathrm{C}, 100 \%$ exit $\mathrm{RH}$ and $\mathrm{SR}_{\mathrm{c}}=2(\mathrm{Q} / \Delta \mathrm{T}=1.8$ $\left.\mathrm{kW} /{ }^{\circ} \mathrm{C}\right)$ to $753 \mathrm{~mW} \cdot \mathrm{cm}^{-2}$ at $663 \mathrm{mV}, 95^{\circ} \mathrm{C}, 91.4 \% \mathrm{RH}$, and $\mathrm{SR}_{\mathrm{c}}=1.5\left(\mathrm{Q} / \Delta \mathrm{T}=1.45 \mathrm{~kW} /{ }^{\circ} \mathrm{C}\right)$.

\section{Nomenclature}

$\begin{array}{llll}\text { A } & \text { specific electrochemical surface area } & \text { D } & \text { water diffusion coefficient } \\ \text { E } & \text { cell voltage, potential or activation energy } & \text { F } & \text { Faraday constant } \\ \text { H } & \text { enthalpy } & \text { h } & \text { mass transfer coefficient } \\ \text { i } & \text { current density } & \text { J } & \text { water transport flux } \\ \text { L } & \text { length or Pt loading } & \text { M } & \text { molecular weight }\end{array}$




$\begin{array}{llll}\dot{N} & \text { molar flow rate } & \mathrm{n} & \text { number of electrons } \\ \mathrm{P} & \text { pressure or power } & \mathrm{Q} & \text { stack heat load } \\ \dot{Q} & \text { heat transfer flux } & \mathrm{R} & \text { gas constant or resistance } \\ \mathrm{T} & \text { temperature } & \mathrm{U} & \text { heat transfer coefficient } \\ \mathrm{W} & \text { width } & \phi & \text { relative humidity } \\ \eta & \text { overpotential or voltage efficiency } & & \end{array}$

\section{Subscripts and Superscripts}

$\begin{array}{llll}0 & \text { standard } & \text { a } & \text { activation, ambient or anode } \\ \text { c } & \text { cathode } & \text { d } & \text { electro-osmotic drag, diffusion layer } \\ \text { L } & \text { limiting } & \text { m } & \text { mass transfer or membrane } \\ \mathrm{N} & \text { Nernst } & \text { R } & \text { reference } \\ \text { r } & \text { reference } & \text { S } & \text { saturation or stack } \\ \text { sc } & \text { cell to stack } & \text { W } & \text { water or coolant } \\ \text { X } & \text { mole fraction } & \text { X } & \text { cross-over or anode flow direction } \\ \alpha & \text { symmetric factor } & \beta & \text { relative humidity dependence } \\ \delta & \text { thickness } & \varepsilon & \text { porosity } \\ \phi & \text { relative humidity } & \gamma & \text { O } \\ \Omega & \text { Ohmic } & \psi & \text { cathode stoichiometry }\end{array}$

\section{Acknowledgments}

This work was supported by the Fuel Cell Technologies Office of the U.S. Department of Energy's (DOE) Office of Energy Efficiency and Renewable Energy. Dr. Nancy Garland is the DOE Technology Development Manager for this work. Argonne is a DOE, Office of Science 
Laboratory operated under Contract No. DE-AC02-06CH11357 by the UChicago Argonne, LLC.

\section{References}

1. R.K. Ahluwalia and X. Wang, Fuel cell systems for transportation: status and trends, J. Power Sources 215 (2008) 167-176.

2. Fuel cell technical team roadmap, www.vehicles.energy.gov/about/partnership/usdrive.html, June 2013.

3. R. Borup, J. Meyers, B. Pivovar et al., Scientific aspects of polymer electrolyte fuel cell durability and degradation, Chem. Rev. (107) (2007) 3904-3951.

4. R.K. Ahluwalia, S. Arisetty, X. Wang, X. Wang, R. Subbaraman, S.C. Ball, S. DeCrane, and D. Myers, Thermodynamics and kinetics of platinum dissolution from carbon-supported electrocatalysts in aqueous media under potentiostatic and potentiodynamic conditions, J. Electrochem. Soc. 160 (2013) F447-F455.

5. R.K. Ahluwalia, S. Arisetty, J-K Peng, R. Subbaraman, X. Wang, N. Kariuki, D.J. Myers, R. Mukundan, R. Borup, and O. Polevaya, Dynamics of particle growth and electrochemical surface area loss due to platinum dissolution, J. Electrochem. Soc. 161 (2013) F291-F304.

6. S. Arisetty, X. Wang, R.K. Ahluwalia, R. Mukundan, R. Borup, J. Davey, D. Langlois, F. Gambini, O. Polevaya, and S. Blanchet, Catalyst durability in PEM fuel cells with low platinum loading, J. Electrochem. Soc. 159 (2012) B455-B462.

7. M. Inaba, Chemical degradation of perfluorinated sulfonic acid membranes, Polymer Electrolyte Fuel Cell Durability, F. N. Buchi et al. (eds.), 57-69, 2009.

8. D.L. Wood and R.L. Borup, Durability aspects of gas-diffusion and microporous layers, Polymer Electrolyte Fuel Cell Durability, F. N. Buchi et al. (eds.), 159-195, 2009. 
9. T. Greszler, Membrane performance and durability overview for automotive fuel cell applications, General Motors Corporation, Sep. 14, 2006.

10. R.K. Ahluwalia, X. Wang, and J-K Peng, Fuel cells systems analysis, 2015 DOE Hydrogen and Fuel Cells Program Review, Washington, D.C., June 8-12, 2015.

11. A.J. Steinbach, C.V. Hamilton, and M.K. Debe, Impact of micromolar concentrations of externally-provided chloride and sulfide contaminants on PEMFC reversible stability, ECS Transactions 11(1) (2007) 889-897.

12. R.K. Ahluwalia, X. Wang, A. Lajunen, A.J. Steinbach, S.M. Hendricks, M.J. Kurkowski, and M.K. Debe, Kinetics of oxygen reduction reaction on nanostructured thin-film platinum alloy catalyst, J. Power Sources 215 (2012) 77-88.

13. X. Wang, R. K. Ahluwalia, X. Wang, and A. J. Steinbach, Kinetics of hydrogen oxidation and hydrogen evolution reactions on nanostructured thin-film platinum alloy catalyst," J. Electrochem. Soc. 160 (2013) F251-F261.

14. R.K. Ahluwalia, X. Wang, J. Kwon, and A. Rousseau, Drive-cycle performance and lifecycle costs of automotive fuel cell systems, 2011 Fuel Cell Seminar \& Exposition, Orlando, FL, Oct. 31 - Nov. 2, 2011.

15. R.K. Ahluwalia, X. Wang, J. Kwon, A. Rousseau, J. Kalinoski, B. James, and J. Marcinkoski, Performance and cost of automotive fuel cell systems with ultra-low platinum loadings, J. Power Sources 196 (2011) 4619.

16. B.D. James, J.A. Kalinoski, and K.N. Baum, Mass production cost estimation for direct $\mathrm{H}_{2}$ PEM fuel cell systems for automotive applications: 2009 update, DTI Report GS-10F-0099J, Jan. 2010. 
17. R.K. Ahluwalia, X. Wang, W.B. Johnson, F. Berg, and D. Kadylak, Performance of crossflow humidifier with a high flux water vapor transport membrane, J. Power Sources 291 (2015) 225-238. 


\section{Tables}

Table 1 Test matrix

Table 2 ORR and HOR kinetic parameters

Table 3 Summary of performance parameters of reference FCS components

Table 4 Parameters of cost correlations

Table 5 Summary of optimum Pt loading study for 2.5 atm stack inlet pressure

Table 6 Effect of variability in supporting data on stack cost and performance 


\section{Figures}

Figure 1 Development and validation of correlations for limiting current density and mass transfer overpotentials a. Limiting current density $\left(80^{\circ} \mathrm{C}\right) \mathrm{b}$. Mass transfer overpotential $\left(80^{\circ} \mathrm{C}\right)$ c. Model validation $\left(80^{\circ} \mathrm{C}\right)$ d. Limiting current density $(2.5 \mathrm{~atm})$ e. Mass transfer overpotential (2.5 atm) f. Model validation (2.5 atm)

Figure 2 Parametric study to illustrate the effect of the stack operating temperature on the costs of the fuel cell system and FCS components a. Dependence of stack and water management system (WMS) cost on coolant exit temperature b. Dependence of FCS cost on coolant exit temperature

Figure 3 Optimization study to determine operating conditions for minimum system cost subject to $\mathrm{Q} / \Delta \mathrm{T}$ constraint, exit $\mathrm{RH}$ restricted to $100 \%$ a. Dependence of optimum coolant temperature on cathode stoichiometry and stack inlet pressure b. Variation of cell voltage with cathode stoichiometry and stack inlet pressure

Figure 4 Optimized system cost and performance subject to $\mathrm{Q} / \Delta \mathrm{T}$ constraint, with and without $100 \%$ exit RH restriction a. System cost b. System performance c. Cell voltage d. Stack power density e. System efficiency f. Stack heat load

Figure 5 Study to determine the optimum Pt loading in the cathode ternary catalyst a. Pt content b. System cost

Figure 6 Impact of stack heat load estimate on system cost and performance a. System cost b. Pt content

Figure 7 Comparison of system cost and performance for representative (REP) and best-of-class (BOC) data a.Variability in polarization curves b. Variability in cell voltage from the mean c. System cost d. Pt content 
Figure 8 Waterfall charts showing changes in power density and FCS cost due to cell-to-stack voltage degradation, rise in coolant temperature, and relaxation of $100 \%$ exit RH constraint a. BOC power density b. Systematic increase in FCS cost c. Cost breakdown for cluster 5 conditions 
Table 1 Test matrix

\begin{tabular}{|c|c|c|c|c|c|c|c|c|c|}
\hline P15 Series & & $\begin{array}{c}\mathrm{L}_{\mathrm{Pt}}(\mathrm{c}) \\
\mathrm{mg} / \mathrm{cm}^{2}\end{array}$ & $\begin{array}{c}\mathrm{L}_{\mathrm{Pt}}(\mathrm{a}) \\
\mathrm{mg} / \mathrm{cm}^{2}\end{array}$ & $\begin{array}{l}\mathrm{T} \\
\mathrm{C}\end{array}$ & $\begin{array}{c}\mathrm{T}_{\mathrm{DP}}(\mathrm{c}) \\
\mathrm{C}\end{array}$ & $\begin{array}{c}\mathrm{T}_{\mathrm{DP}}(\mathrm{a}) \\
\mathrm{C}\end{array}$ & $\begin{array}{c}\mathrm{P} \\
\mathrm{atm}\end{array}$ & $\mathrm{SR}(\mathrm{c})$ & $\mathrm{SR}(\mathrm{a})$ \\
\hline \multirow{2}{*}{$\begin{array}{l}\text { Reference } \\
\text { Conditions }\end{array}$} & FC19478 & 0.1 & 0.05 & 80 & 65 & 65 & 1.5 & 2 & 2 \\
\hline & FC19453 & 0.1 & 0.05 & 80 & 65 & 65 & 1.5 & 2 & 2 \\
\hline Test Series & Tests & 1 & 2 & 3 & 4 & 5 & 6 & 7 & 8 \\
\hline T Series & $\mathrm{T}(\mathrm{C}) / \mathrm{T}_{\mathrm{DP}}(\mathrm{C})$ & $75 / 55$ & $80 / 65$ & $85 / 74$ & $90 / 82$ & & & & \\
\hline P Series & $\mathrm{P}(\mathrm{atm}) / \mathrm{T}_{\mathrm{DP}}(\mathrm{C})$ & $1 / 73$ & $1.25 / 70$ & $1.5 / 65$ & $2 / 56$ & $2.5 / 40$ & & & \\
\hline RH Series & $\mathrm{T}_{\mathrm{DP}}(\mathrm{C})$ & 0 & 50 & 55 & 60 & 65 & 70 & 75 & 80 \\
\hline$L_{P t}$ Series & $\mathrm{L}_{\mathrm{Pt}}(\mathrm{c})\left(\mathrm{mg} / \mathrm{cm}^{2}\right)$ & 0.05 & 0.1 & 0.15 & 0.2 & & & & \\
\hline $\mathrm{SR}_{\mathrm{c}}$ Series & $\mathrm{SR}(\mathrm{c}) / \mathrm{T}_{\mathrm{DP}}(\mathrm{C})$ & $1.5 / 60$ & $2 / 65$ & $2.5 / 68$ & $5 / 75$ & & & & \\
\hline SRa Series & $\mathrm{SR}_{0}(\mathrm{a})$ & 1.2 & 1.5 & 2 & 2.5 & 5 & & & \\
\hline Cold T Series & $\mathrm{T}(\mathrm{C}) / \mathrm{T}_{\mathrm{DP}}(\mathrm{C})$ & $30 / 0$ & $45 / 0$ & $60 / 0$ & & & & & \\
\hline Idle Operation & $\mathrm{T}(\mathrm{C}) / \mathrm{P}(\mathrm{atm}) / \mathrm{SR}(\mathrm{c})$ & $80 / 1.05 / 10$ & $80 / 1.1 / 5$ & $80 / 1.2 / 2.5$ & $80 / 1.3 / 1.75$ & & & & \\
\hline \multirow{2}{*}{ P25 Series } & & $\mathrm{L}_{\mathrm{Pt}}(\mathrm{c})$ & $L_{P t}(a)$ & $T$ & $\mathrm{~T}_{\mathrm{DP}}(\mathrm{c})$ & $\mathrm{T}_{\mathrm{DP}}(\mathrm{a})$ & $\mathrm{P}$ & $\mathrm{SR}(\mathrm{c})$ & $\mathrm{SR}(\mathrm{a})$ \\
\hline & & $\mathrm{mg} / \mathrm{cm}^{2}$ & $\mathrm{mg} / \mathrm{cm}^{2}$ & C & C & $\mathrm{C}$ & atm & & \\
\hline \multirow{2}{*}{$\begin{array}{l}\text { Reference } \\
\text { Conditions }\end{array}$} & FC23102 & 0.1 & 0.05 & 85 & 65 & 65 & 2.5 & 2 & 2 \\
\hline & FC23272 & 0.15 & 0.05 & 85 & 65 & 65 & 2.5 & 2 & 2 \\
\hline Test Series & Tests & 1 & 2 & 3 & 4 & 5 & 6 & 7 & 8 \\
\hline T Series & $\mathrm{T}(\mathrm{C}) / \mathrm{T}_{\mathrm{DP}}(\mathrm{C})$ & $75 / 25$ & $80 / 50$ & $85 / 65$ & $90 / 75$ & & & & \\
\hline RH Series & $\mathrm{T}_{\mathrm{DP}}(\mathrm{C})$ & 50 & 55 & 60 & 65 & 70 & 75 & 80 & 85 \\
\hline $\mathrm{SR}_{\mathrm{c}}$ Series & $\mathrm{SR}(\mathrm{c}) / \mathrm{T}_{\mathrm{DP}}(\mathrm{C})$ & $1.5 / 52$ & $2 / 65$ & $2.5 / 70$ & $5 / 79$ & & & & \\
\hline \multirow{2}{*}{$\begin{array}{l}\text { SR }_{a} \text { Series } \\
\text { Cold T Series }\end{array}$} & $\mathrm{SR}(\mathrm{a})$ & 1.2 & 1.5 & 2 & 2.5 & 5 & & & \\
\hline & $\mathrm{T}(\mathrm{C}) / \mathrm{T}_{\mathrm{DP}}(\mathrm{C})$ & $30 / 0$ & $45 / 0$ & $60 / 0$ & & & & & \\
\hline \multirow{2}{*}{ P30 Series } & & $\mathrm{L}_{\mathrm{Pt}}(\mathrm{c})$ & $\mathrm{L}_{\mathrm{Pt}}(\mathrm{a})$ & $\mathrm{T}$ & $\mathrm{T}_{\mathrm{DP}}(\mathrm{c})$ & $\mathrm{T}_{\mathrm{DP}}(\mathrm{a})$ & $P$ & $\mathrm{SR}(\mathrm{c})$ & $\mathrm{SR}(\mathrm{a})$ \\
\hline & & $\mathrm{mg} / \mathrm{cm}^{2}$ & $\mathrm{mg} / \mathrm{cm}^{2}$ & $\mathrm{C}$ & C & $\mathrm{C}$ & atm & & \\
\hline \multirow{2}{*}{$\begin{array}{l}\text { Reference } \\
\text { Conditions }\end{array}$} & FC26115 & 0.15 & 0.05 & 90 & 64 & 64 & 3 & 2 & 2 \\
\hline & FC25979 & 0.15 & 0.05 & 90 & 64 & 64 & 3 & 2 & 2 \\
\hline Test Series & Tests & 1 & 2 & 3 & 4 & 5 & 6 & & \\
\hline T Series & $\mathrm{T}(\mathrm{C}) / \mathrm{T}_{\mathrm{DP}}(\mathrm{C})$ & $80 / 0$ & $85 / 46$ & $90 / 64$ & $95 / 76$ & & & & \\
\hline P Series & $\mathrm{P}(\mathrm{atm}) / \mathrm{T}(\mathrm{C}) / \mathrm{T}_{\mathrm{DP}}(\mathrm{C})$ & $1.5 / 80 / 65$ & $2.5 / 85 / 65$ & $3 / 90 / 64$ & & & & & \\
\hline RH Series & $\mathrm{T}_{\mathrm{DP}}(\mathrm{C})$ & 50 & 60 & 64 & 70 & 80 & 90 & & \\
\hline $\mathrm{SR}_{\mathrm{c}}$ Series & $\mathrm{SR}(\mathrm{c}) / \mathrm{T}_{\mathrm{DP}}(\mathrm{C})$ & $1.5 / 0$ & $2 / 64$ & $2.5 / 70$ & $5 / 81$ & & & & \\
\hline Cold T Series & $\mathrm{T}(\mathrm{C}) / \mathrm{T}_{\mathrm{DP}}(\mathrm{C})$ & $30 / 0$ & $45 / 0$ & $60 / 0$ & $70 / 0$ & & & & \\
\hline
\end{tabular}


Table 2 ORR and HOR kinetic parameters

\begin{tabular}{|c|c|c|c|c|c|c|c|}
\hline \multicolumn{8}{|c|}{ a. ORR Kinetics $\left(T_{R}=353 \mathrm{~K}\right)$} \\
\hline $\begin{array}{c}L_{P t} \\
\text { mg.cm }\end{array}$ & $\begin{array}{c}\boldsymbol{A}_{\boldsymbol{P t} t}^{\mathbf{0}} \\
\mathrm{m}_{\mathrm{Pt}}^{2} \cdot \mathrm{g}_{\mathrm{Pt}}^{-1}\end{array}$ & $\mathrm{~mA}_{\mathrm{Or}}^{\mathrm{i}_{\mathrm{r}}}$ & $\begin{array}{c}\mathrm{E}_{\mathrm{ORR}} \\
\mathrm{kJ} \cdot \mathrm{mol}^{-1}\end{array}$ & $\mathrm{n}$ & $\alpha_{c}^{c}$ & $\beta$ & $\gamma$ \\
\hline 0.1 & 9.8 & $0.1 \times 10^{-3}$ & 56 & 2 & 0.51 & 0.9 & 0.45 \\
\hline \multicolumn{8}{|c|}{ b. HOR Kinetics $\left(T_{R}=353 \mathrm{~K}\right)$} \\
\hline $\begin{array}{c}L_{P t} \\
\mathrm{mg} \cdot \mathrm{cm}^{-2}\end{array}$ & $\begin{array}{c}\boldsymbol{A}_{\boldsymbol{P t}}^{\mathbf{0}} \\
\mathrm{m}_{\mathrm{Pt}}^{2} \cdot \mathrm{g}_{\mathrm{Pt}}^{-1}\end{array}$ & $\mathrm{~mA}_{\mathrm{Or}}^{\mathrm{i}_{\mathrm{r}}}$ & $\begin{array}{c}\mathrm{E}_{\mathrm{HOR}} \\
\mathrm{kJ} \cdot \mathrm{mol}^{-1}\end{array}$ & $\mathrm{n}$ & $\alpha_{a}^{a}$ & $\alpha_{c}^{a}$ & \\
\hline 0.05 & 11.2 & 489 & 38.9 & 2 & 0.5 & 0.5 & \\
\hline
\end{tabular}


Table 3 Summary of performance parameters of reference FCS components

\section{PEFC Stack}

- 1.5-3 atm at rated power

- $40-67 \% \mathrm{O}_{2}$ utilization $\left(\mathrm{SR}_{\mathrm{c}}: 1.5-2.5\right)$

- $50 \% \mathrm{H}_{2}$ consumption per pass

- Cell voltage at rated power: TBD

- 24- $\mu \mathrm{m}$ 3M membrane at TBD temperature

- $3 \mathrm{M}$ ternary alloy: $0.1 / 0.05 \mathrm{mg}-\mathrm{Pt} / \mathrm{cm}^{2}$ on cathode/anode

- GDL: 235- $\mu \mathrm{m}$ non-woven carbon fiber with MPL

- 1.1-mm metal bipolar plates, each with cooling channels

- 17 cells/inch

\section{Fuel Management System}

- Hybrid ejector-recirculation pump

- $35 \%$ pump efficiency

- 3 psi pressure drop at rated power

\section{Air Management System}

- Compressor-expander module

- Liquid-cooled motor

- Efficiencies at rated power: $71 \%$ compressor, $73 \%$ expander, $89.5 \%$ motor, $89.5 \%$ controller

- Turn-down: 20

- 5 psi pressure drop at rated power Heat Rejection System

- Two circuits: $75-95^{\circ} \mathrm{C} \mathrm{HT}, 10^{\circ} \mathrm{C} \Delta \mathrm{T}$ $65^{\circ} \mathrm{C} \mathrm{LT}$ coolant, $5^{\circ} \mathrm{C} \Delta \mathrm{T}$

- $55 \%$ pump + 92\% motor efficiency

- $45 \%$ blower + 92\% motor efficiency

- 10 psi pressure drop each in stack and radiator

\section{Water Management System}

- Membrane humidifier, TBD dew-point temperature at rated power

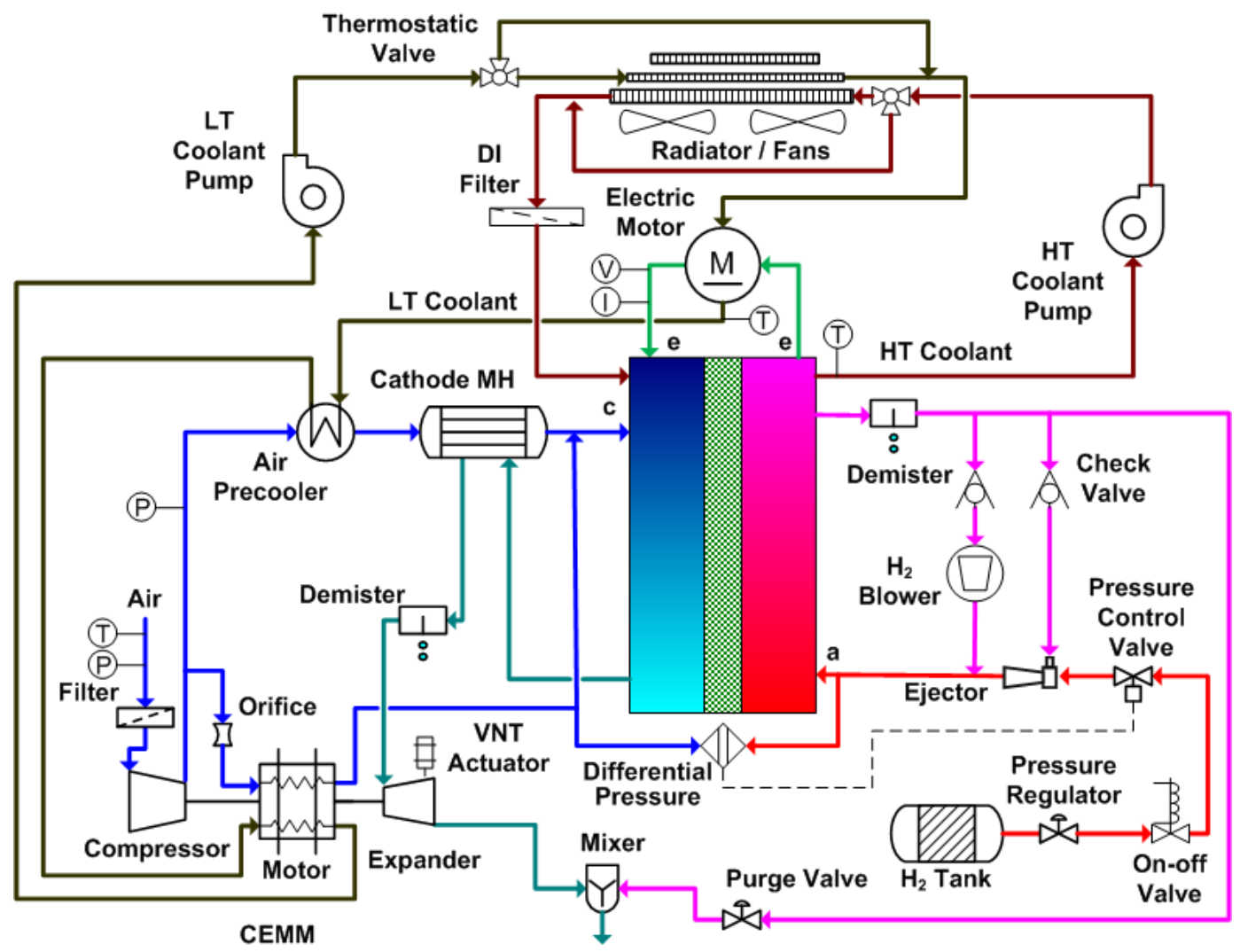


Table 4 Parameters of cost correlations

\begin{tabular}{|c|c|c|c|}
\hline Component & Variable & Validation Range & Cost Model \\
\hline \multirow{3}{*}{$\begin{array}{l}\text { Stack } \\
(300 V)\end{array}$} & $\mathrm{A}, \mathrm{cm}^{2}$ & {$[63655,124938]$} & \multirow{3}{*}{$\begin{array}{l}3.71 \times 10^{-5}(0.87 A-2.57) L_{P t} C \\
+6.70 \times 10^{-3} A+399.2\end{array}$} \\
\hline & $\mathrm{L}_{\mathrm{Pt}}, \mathrm{mg} \cdot \mathrm{cm}^{-2}$ & {$[0.1,0.8]$} & \\
\hline & $\mathrm{C}, \$ /$ tr-oz & {$[800,2000]$} & \\
\hline \multirow{2}{*}{$\begin{array}{c}\text { Air } \\
\text { Management }\end{array}$} & $\mathrm{P}$, atm & {$[1.5,3.15]$} & \multirow{2}{*}{$515.9-2.14 P+0.62 P \dot{m}_{\text {air }}$} \\
\hline & $\dot{m}_{\text {air }}, \mathrm{kg} / \mathrm{h}$ & {$[200,400]$} & \\
\hline \multirow{4}{*}{$\begin{array}{c}\text { Thermal } \\
\text { Management }\end{array}$} & $\mathrm{Q}_{\mathrm{HT}}, \mathrm{kW}$ & {$[56,109]$} & \multirow{4}{*}{$\begin{array}{l}\left(100.25 Q_{H T} / \Delta T_{H T}+190.9\right) \\
+\left(302.17\left(Q_{L T} / \Delta T_{L T}\right)^{2}+313.06 Q_{L T} / \Delta T_{L T}\right) \\
+\left(8.36 P^{2}-25.47 P-99.48 P Q_{L T} / \Delta T_{L T}\right) \\
+17.77\end{array}$} \\
\hline & $\Delta \mathrm{T}_{\mathrm{HT}}, \mathrm{K}$ & {$[38,70]$} & \\
\hline & $\mathrm{Q}_{\mathrm{LT}}, \mathrm{kW}$ & {$[17,27]$} & \\
\hline & $\Delta \mathrm{T}_{\mathrm{LT}}, \mathrm{K}$ & {$[28,70]$} & \\
\hline \multirow{3}{*}{$\begin{array}{c}\text { Water } \\
\text { Management }\end{array}$} & $\mathrm{A}, \mathrm{m}^{2}$ & {$[0.32,4.25]$} & \multirow{3}{*}{$\begin{array}{l}\left(-1.04 A^{2}+48.01 A+16.6\right) \\
+(588.69 Q / \Delta T-2.7)\end{array}$} \\
\hline & $\mathrm{Q}, \mathrm{kW}$ & {$[5.5,10.9]$} & \\
\hline & $\Delta \mathrm{T}, \mathrm{K}$ & {$[97,100]$} & \\
\hline \multirow{2}{*}{$\begin{array}{c}\text { Fuel } \\
\text { Management }\end{array}$} & $\mathrm{P}, \mathrm{kW}$ & {$[0.1,0.25]$} & $\left(3801.97 P^{3}-2967.73 P^{2}-1573.1 P-87.8\right)$ \\
\hline & & & +241.3 \\
\hline BOP & & & 551.9 \\
\hline
\end{tabular}

Cost variables

Stack: A: active membrane area; C: Pt price

Air management system: P: compressor discharge pressure; $\dot{m}_{\text {air }}$ : air flow rate

Thermal management system: HT: high temperature radiator; LT: low temperature radiator;

Q: heat load; $\Delta \mathrm{T}: \mathrm{T}-\mathrm{T}_{\mathrm{a}}$

Water management system: A: humidifier membrane area; Q: pre-cooler heat load

Fuel management system: P: blower power 
Table 5 Summary of optimum Pt loading study for 2.5 atm stack inlet pressure

$\begin{array}{llcccc}\text { Pt Loading } & \mathrm{mg} / \mathrm{cm}^{2} & 0.054 & 0.103 & 0.146 & 0.186 \\ \text { Power Density } & \mathrm{mW} / \mathrm{cm}^{2} & 565 & 672 & 703 & 690 \\ \text { Pt Cost } & \$ / \mathrm{kW}_{\mathrm{e}} & 9.8 & 12.1 & 14.8 & 18.2 \\ \text { Stack Cost } & \$ / \mathrm{kW}_{\mathrm{e}} & 28.0 & 28.2 & 30.4 & 34.0\end{array}$


Table 6 Effect of variability in supporting data on stack cost and performance

\begin{tabular}{llcccc} 
& & \multicolumn{2}{c}{$2.5 \mathrm{~atm}, 95^{\circ} \mathrm{C}$} & \multicolumn{2}{c}{$1.5 \mathrm{~atm}, 87^{\circ} \mathrm{C}$} \\
& & REP & BOC & REP & BOC \\
Cell Voltage & $\mathrm{mV}$ & 662 & 662 & 697 & 697 \\
Current Density & $\mathrm{A} / \mathrm{cm}^{2}$ & 1.02 & 1.14 & 0.57 & 0.64 \\
Power Density & $\mathrm{mW} / \mathrm{cm}^{2}$ & 674 & 753 & 394 & 447 \\
Pt Cost & $\$ / \mathrm{kW}_{\mathrm{e}}$ & 12.1 & 10.8 & 19.9 & 17.5 \\
Stack Cost & $\$ / \mathrm{kW}_{\mathrm{e}}$ & 28.1 & 25.7 & 43.1 & 38.5
\end{tabular}




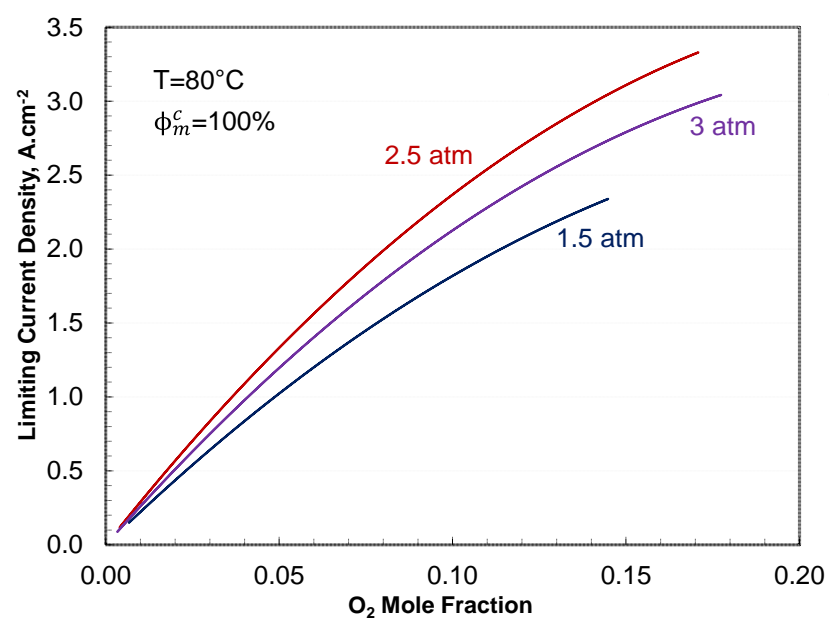

(a) Limiting current density $\left(80^{\circ} \mathrm{C}\right)$

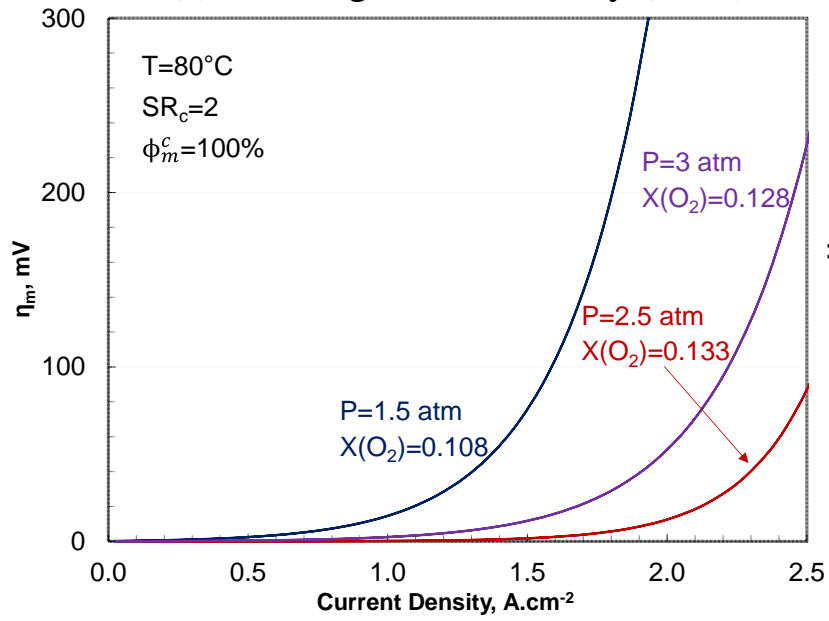

(b) Mass transfer overpotential $\left(80^{\circ} \mathrm{C}\right)$

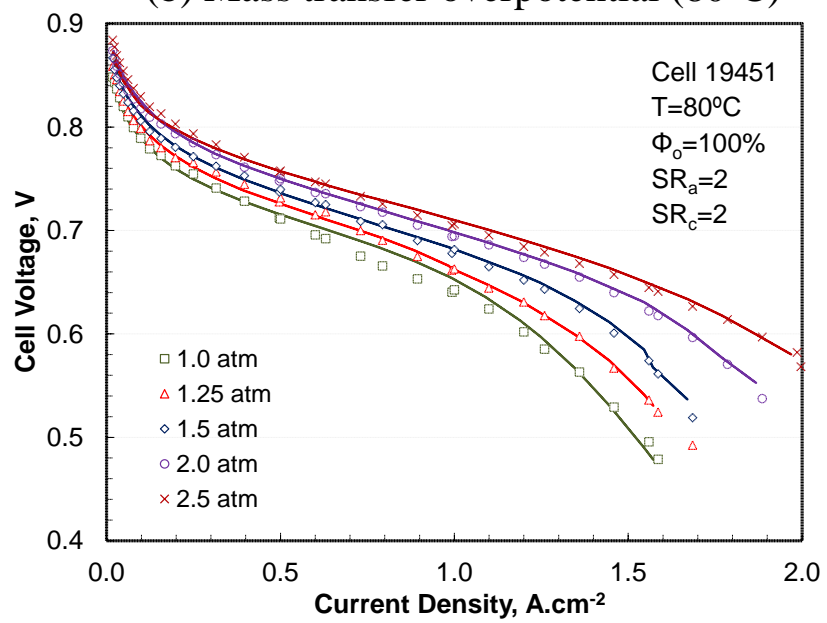

(c) Model validation $\left(80^{\circ} \mathrm{C}\right)$

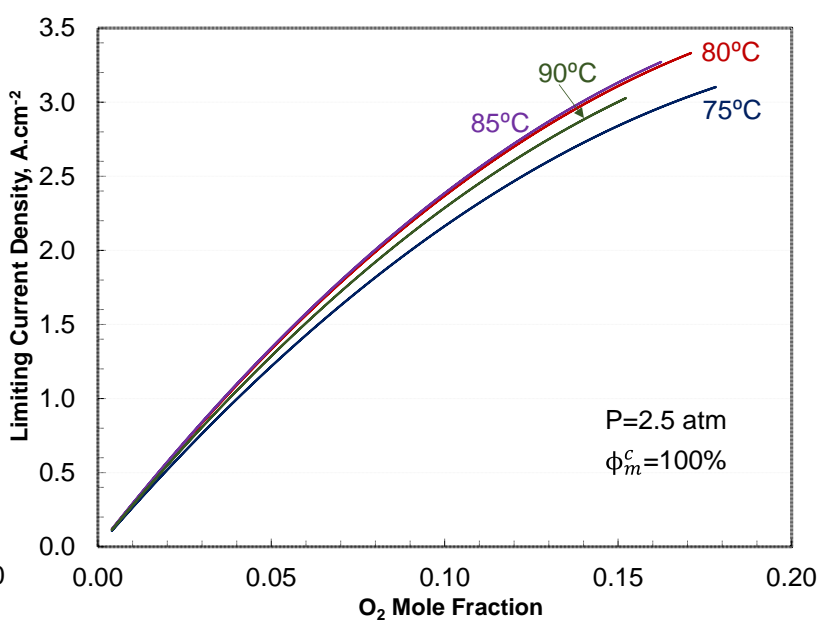

(d) Limiting current density (2.5 atm)

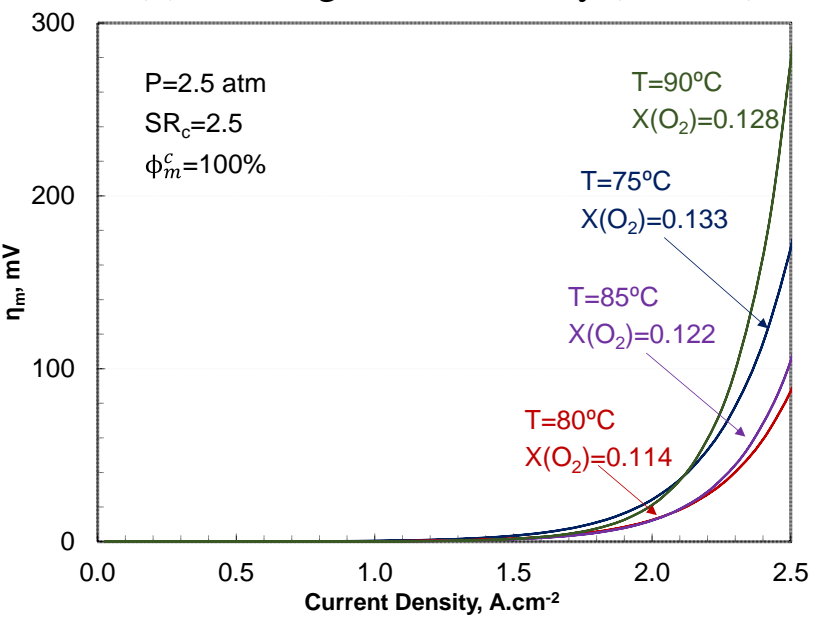

(e) Mass transfer overpotential (2.5 atm)

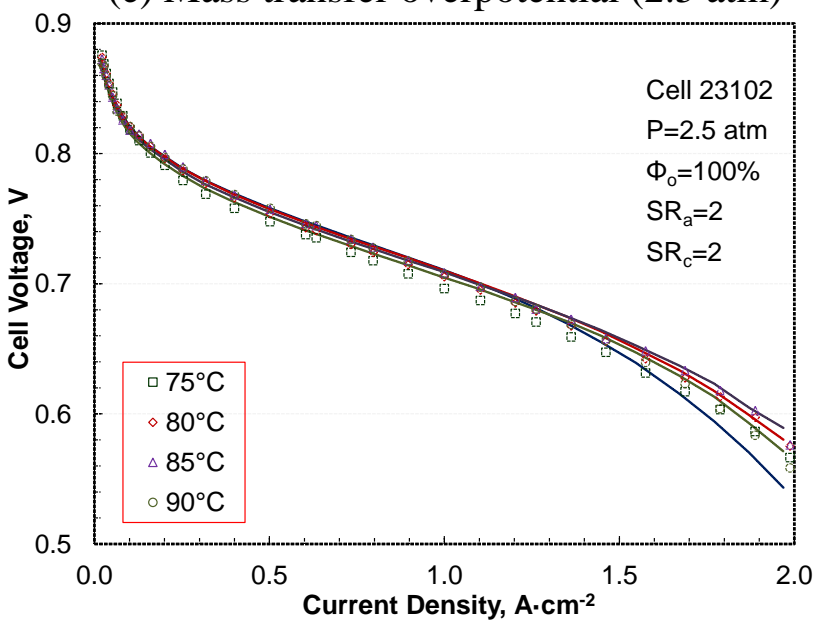

(f) Model validation (2.5 atm)

Figure 1 Development and validation of correlations for limiting current density and mass transfer overpotentials 


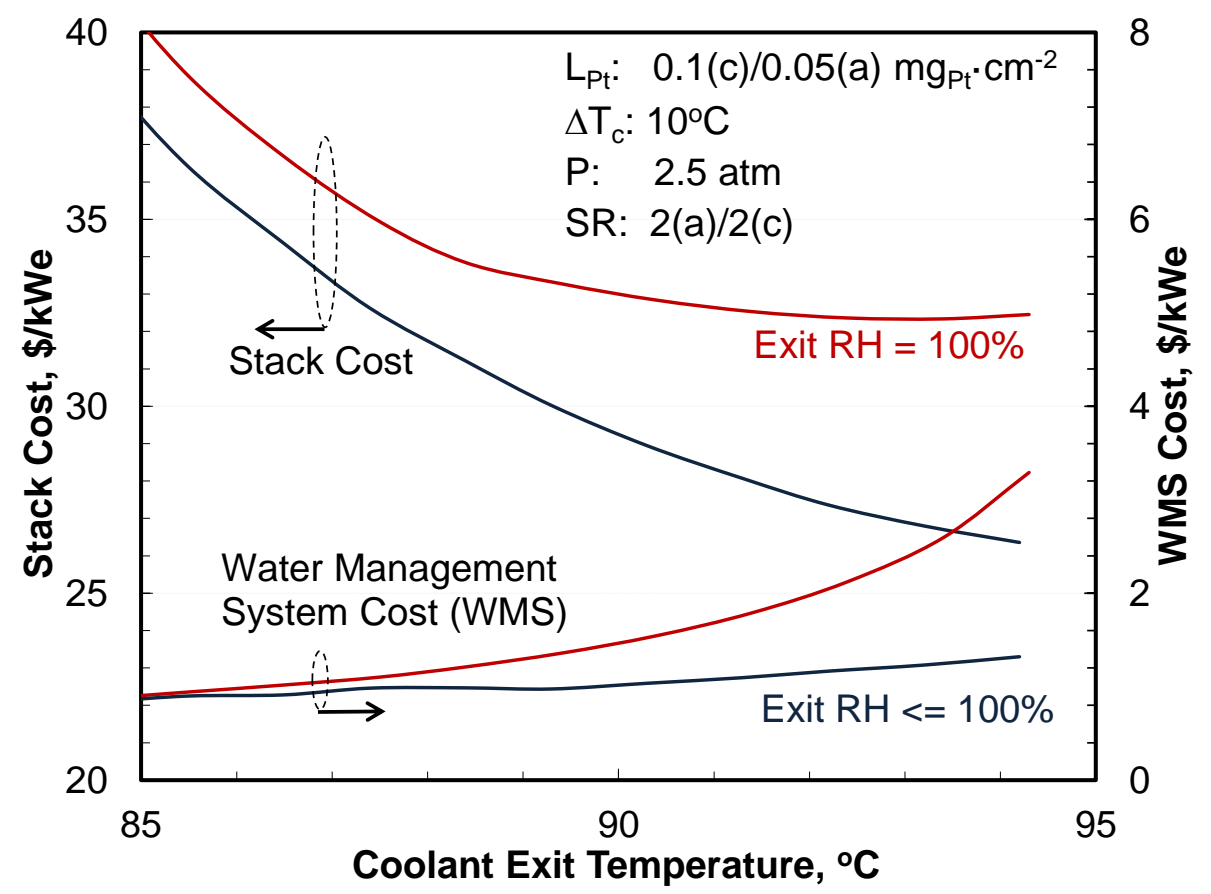

(a) Dependence of stack and water management system (WMS) cost on coolant exit temperature

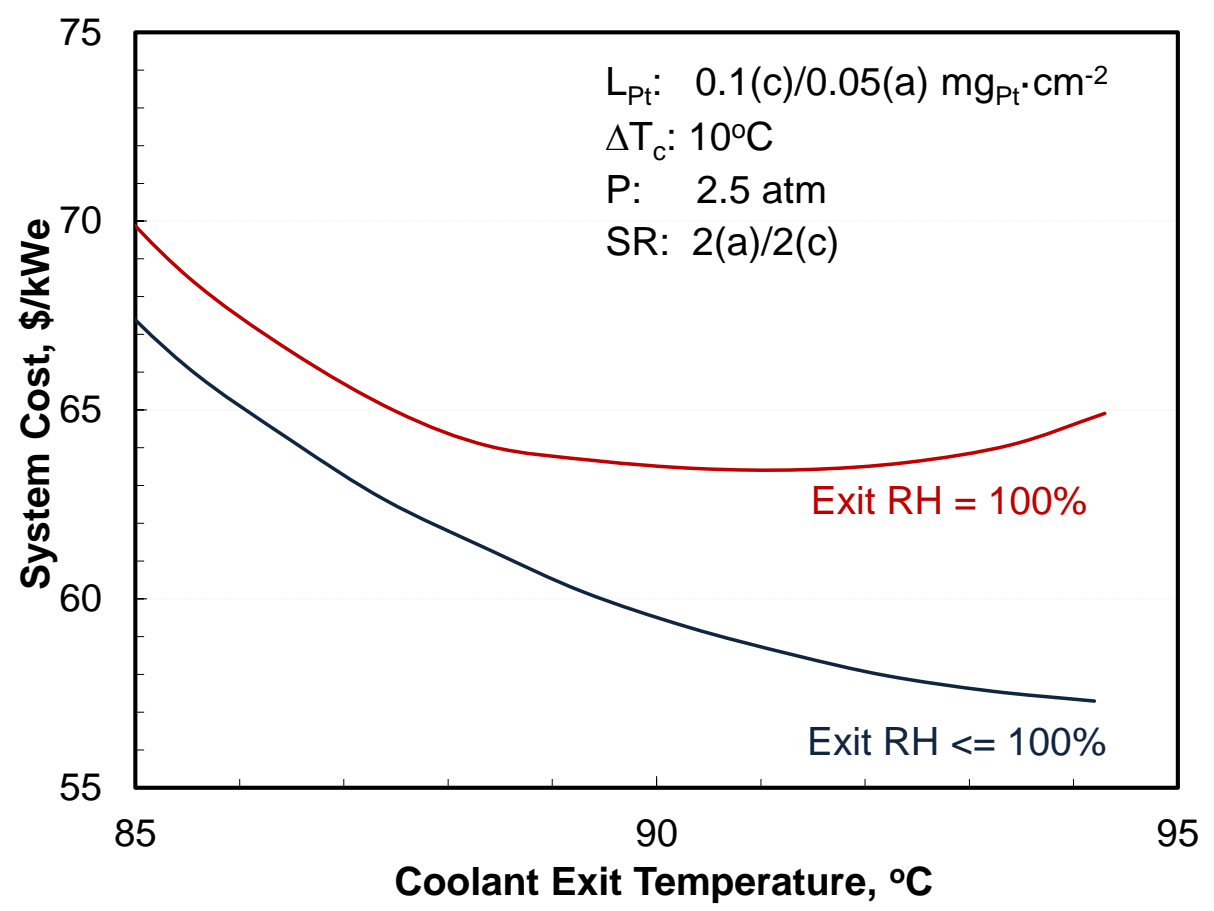

(b) Dependence of FCS cost on coolant exit temperature

Figure 2 Parametric study to illustrate the effect of the stack operating temperature on the costs of the fuel cell system and FCS components 


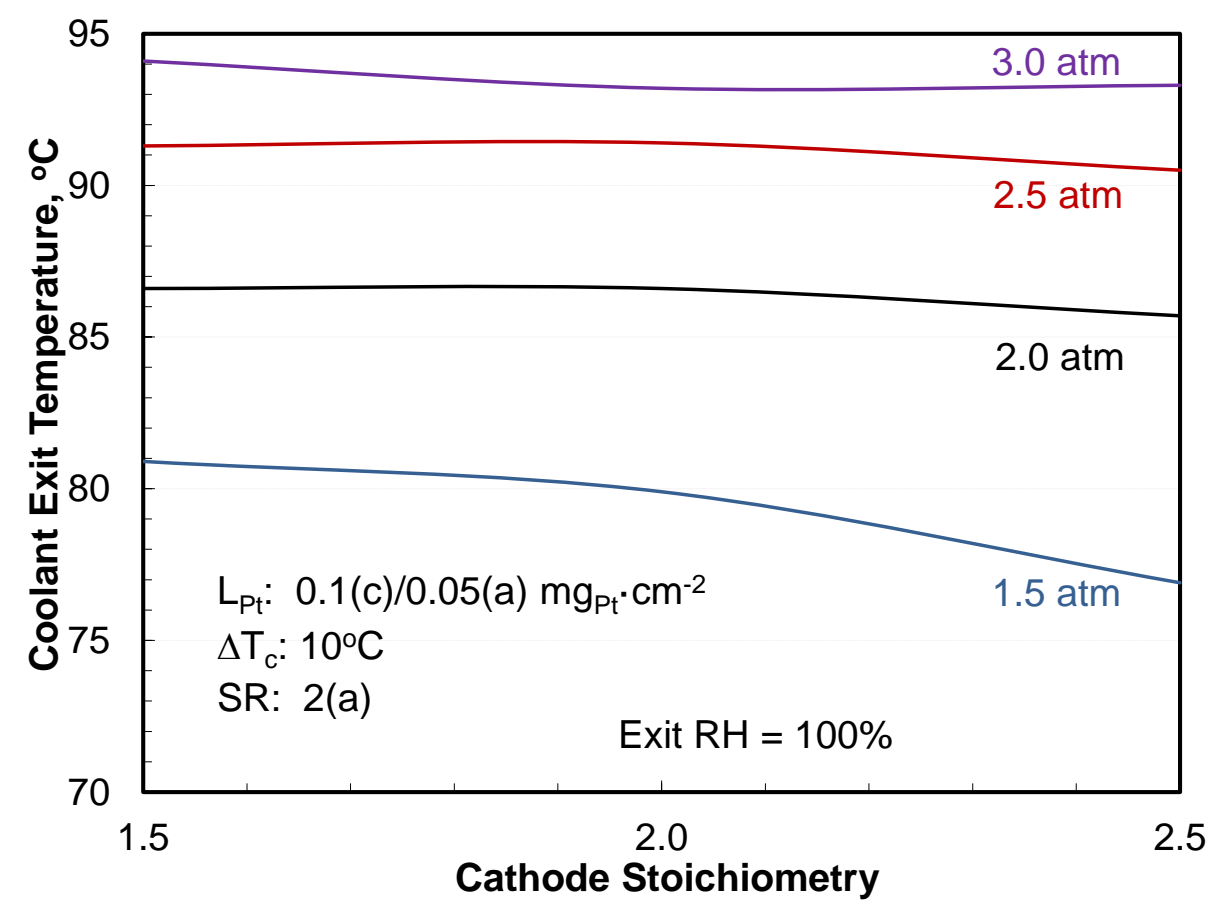

(a) Dependence of optimum coolant temperature on cathode stoichiometry and stack inlet pressure

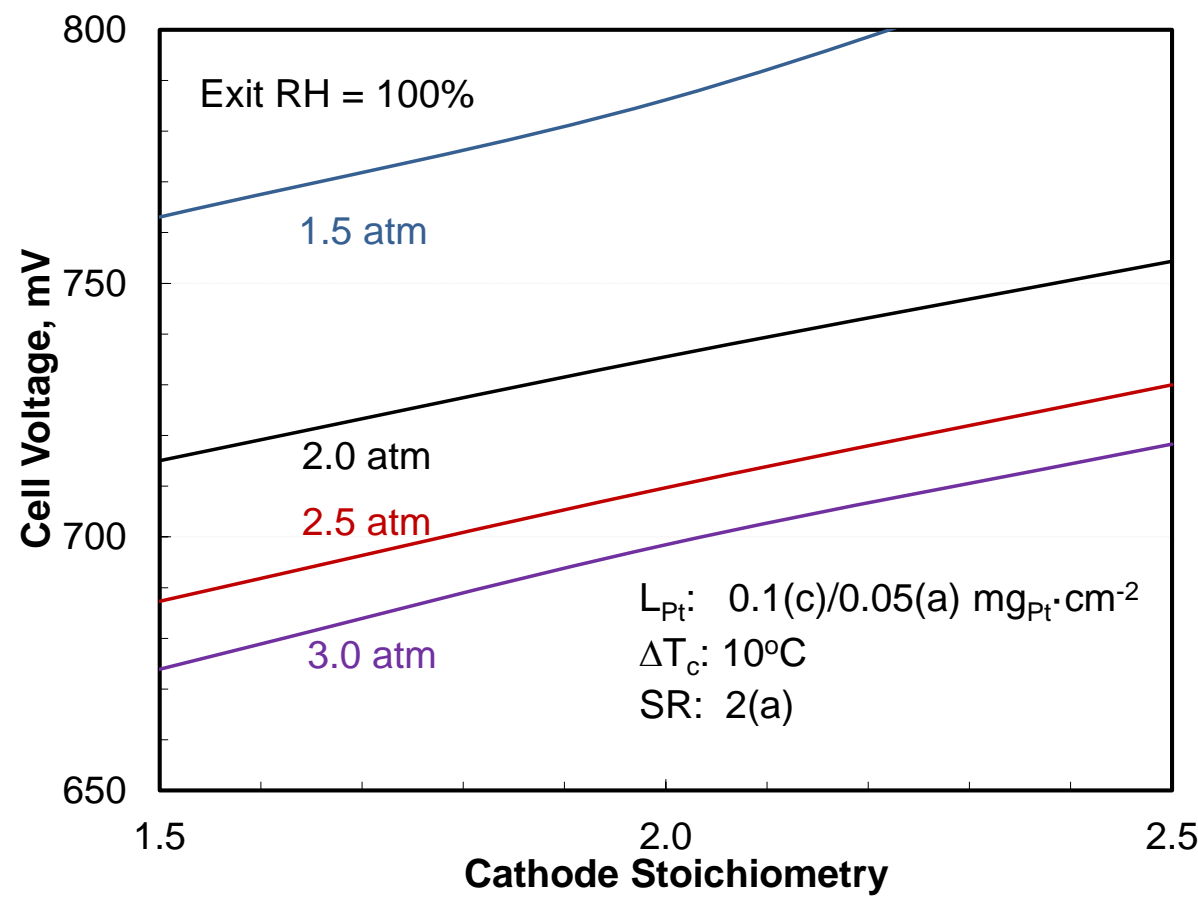

(b) Variation of cell voltage with cathode stoichiometry and stack inlet pressure

Figure 3 Optimization study to determine operating conditions for minimum system cost subject to $\mathrm{Q} / \Delta \mathrm{T}$ constraint, exit $\mathrm{RH}$ restricted to $100 \%$ 


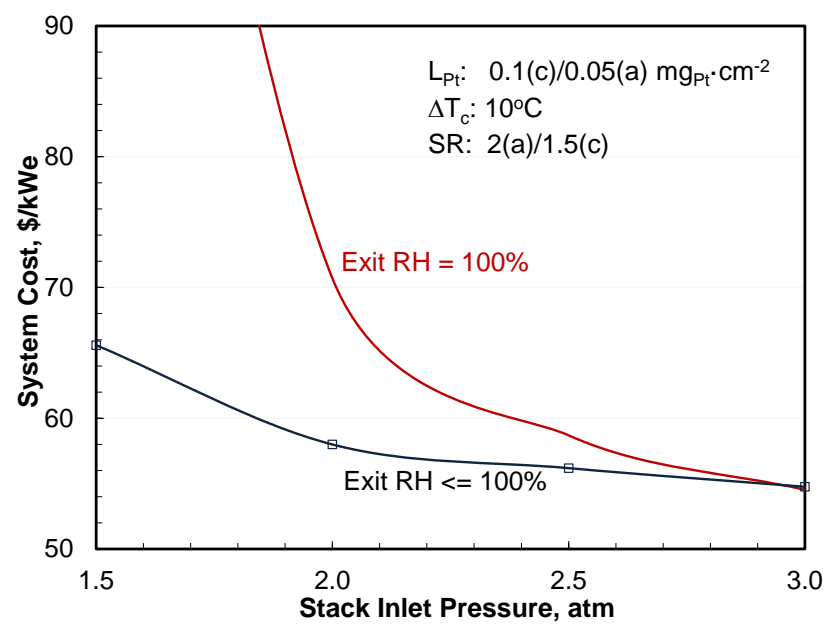

(a) System cost

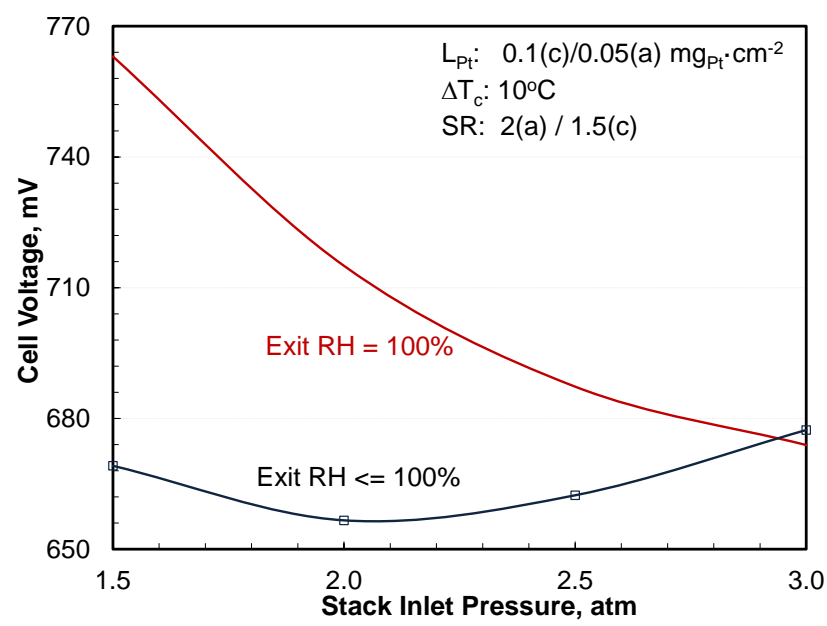

(c) Cell voltage

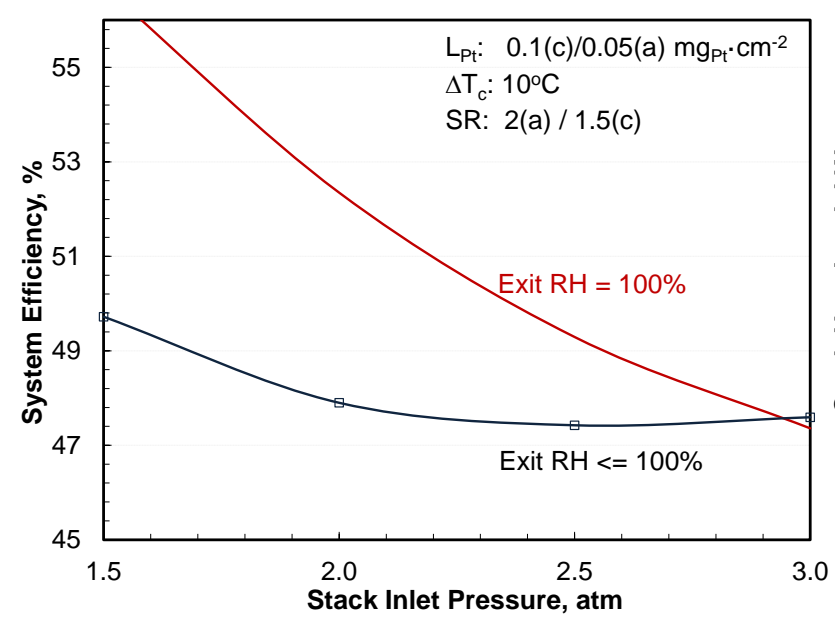

(e) System efficiency

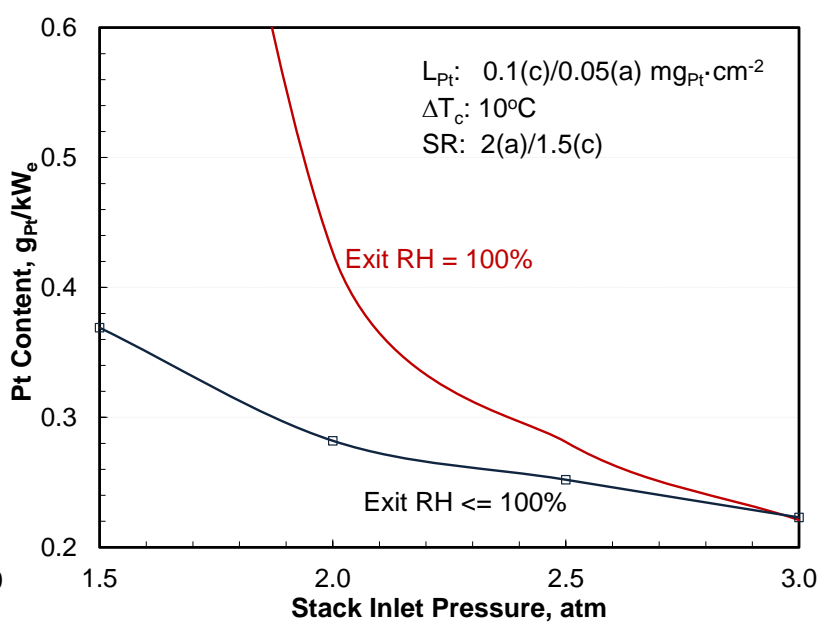

(b) System performance

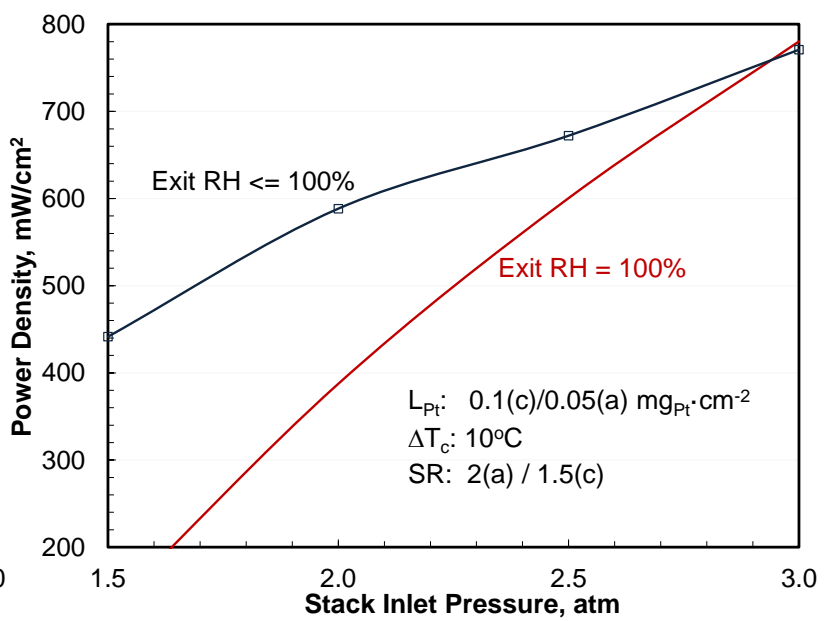

(d) Stack power density

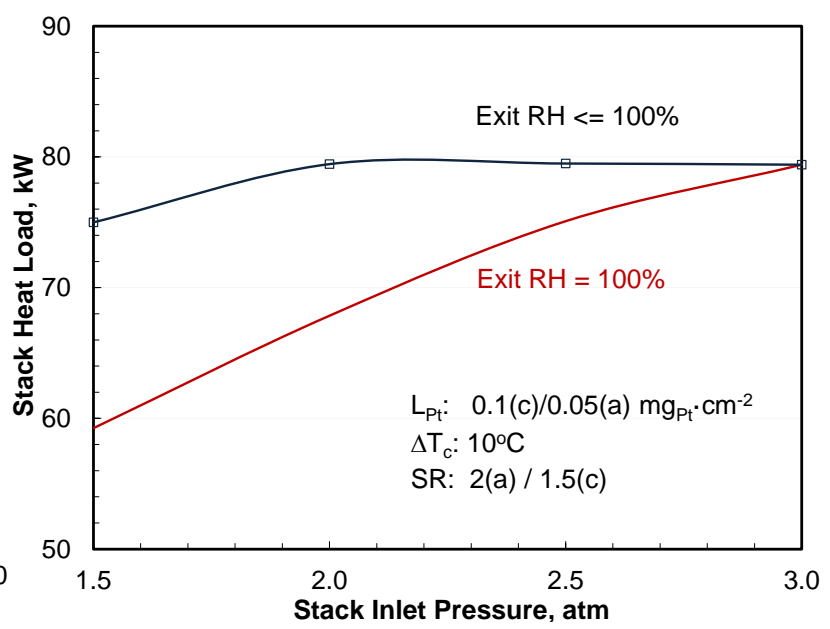

(f) Stack heat load

Figure 4 Optimized system cost and performance subject to $\mathrm{Q} / \Delta \mathrm{T}$ constraint, with and without $100 \%$ exit RH restriction 


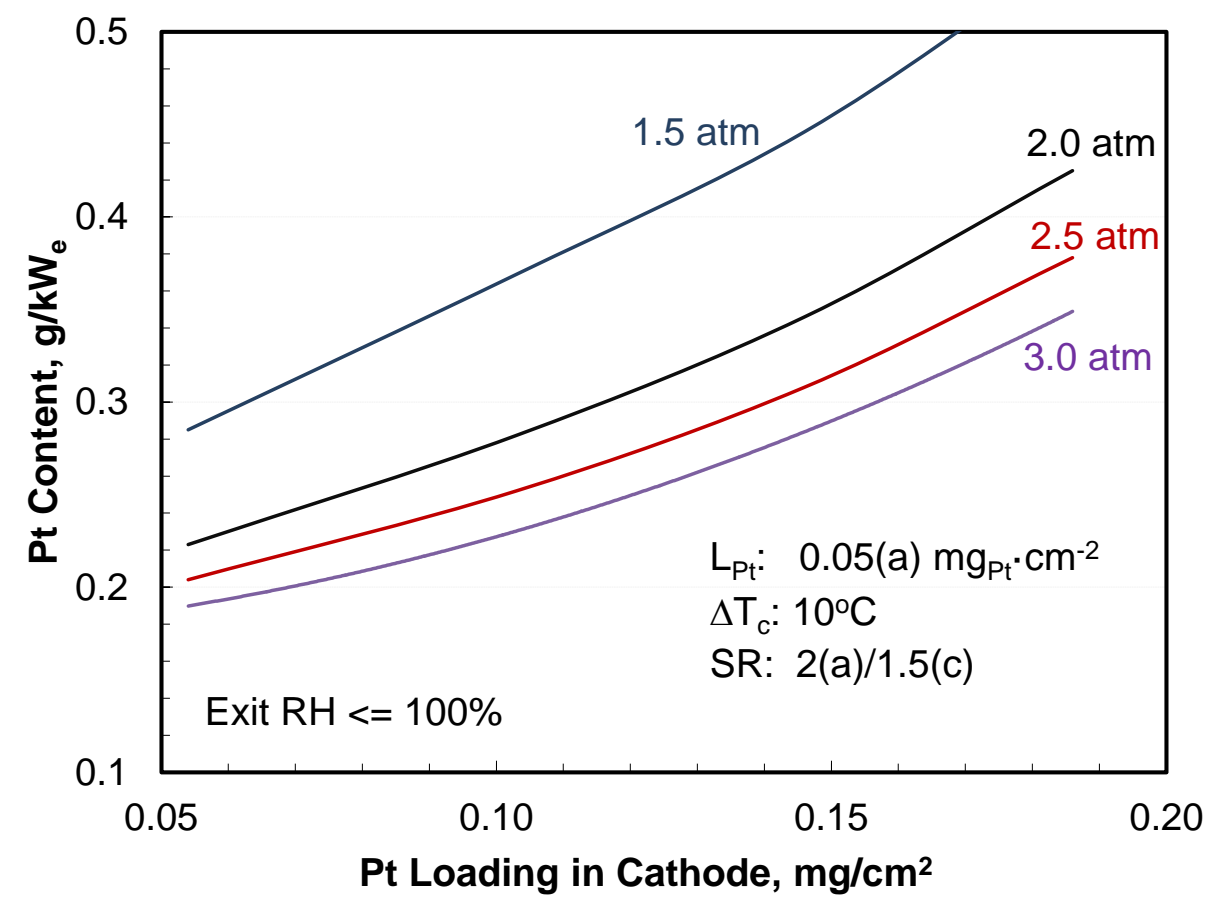

(a) Pt content

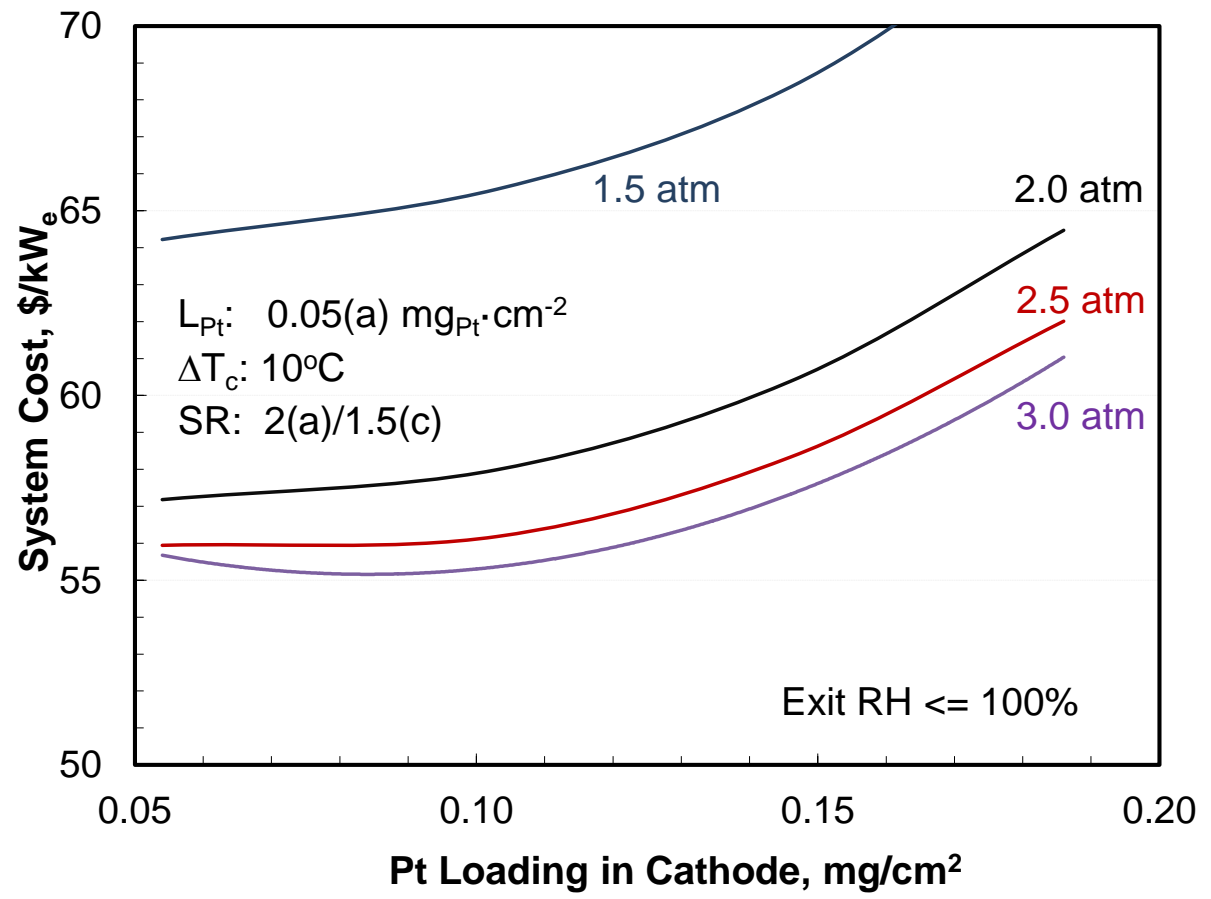

(a) System cost

Figure 5 Study to determine the optimum Pt loading in the cathode ternary catalyst 


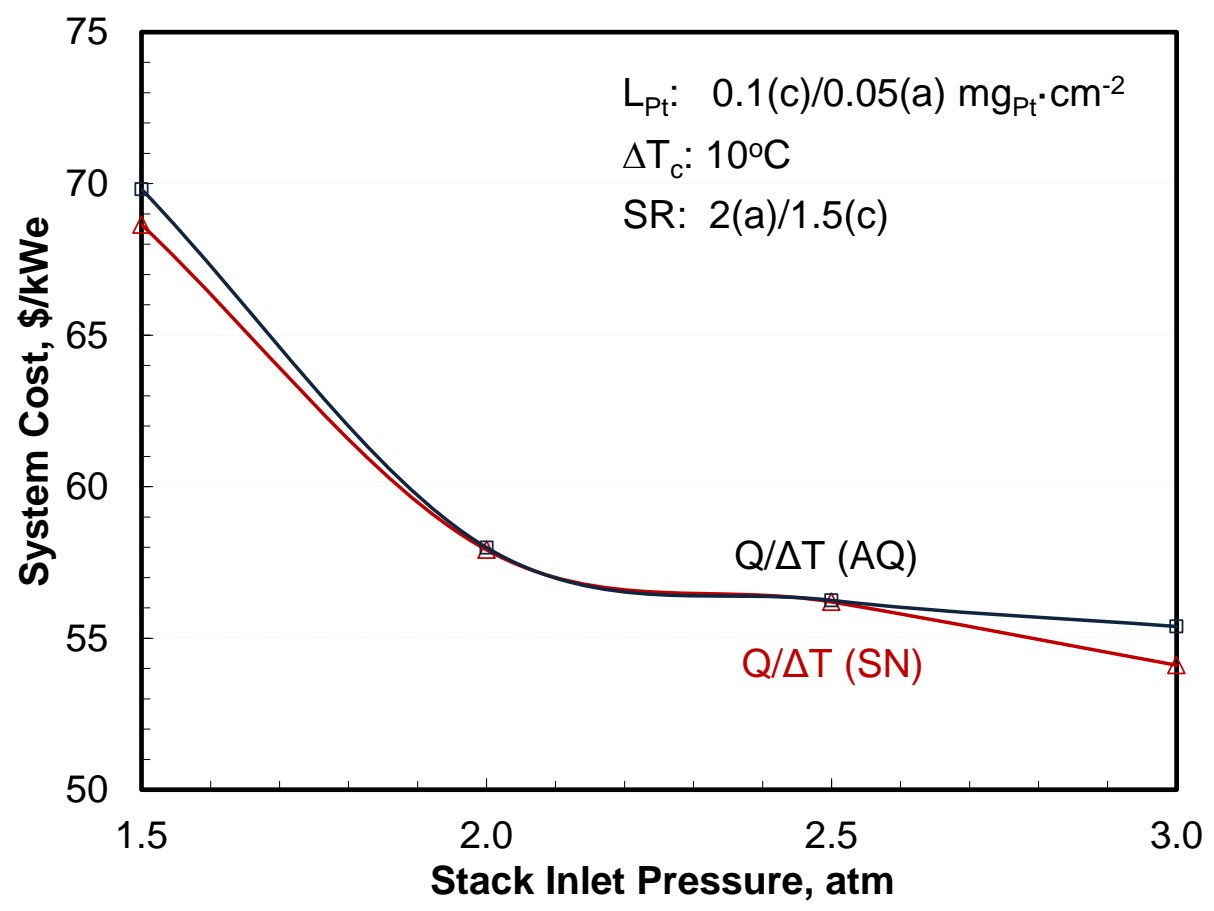

(a) System cost

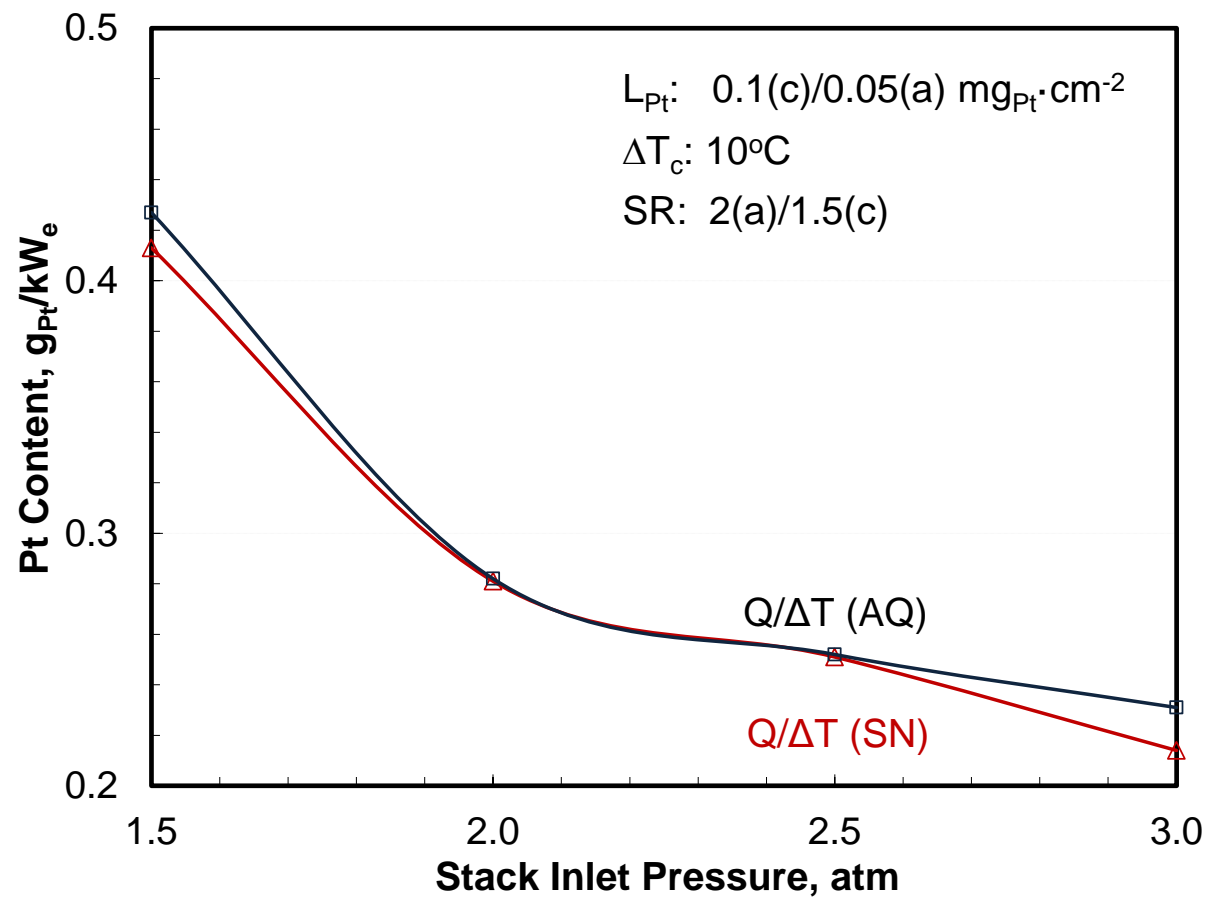

(b) Pt content

Figure 6 Impact of stack heat load estimate on system cost and performance 


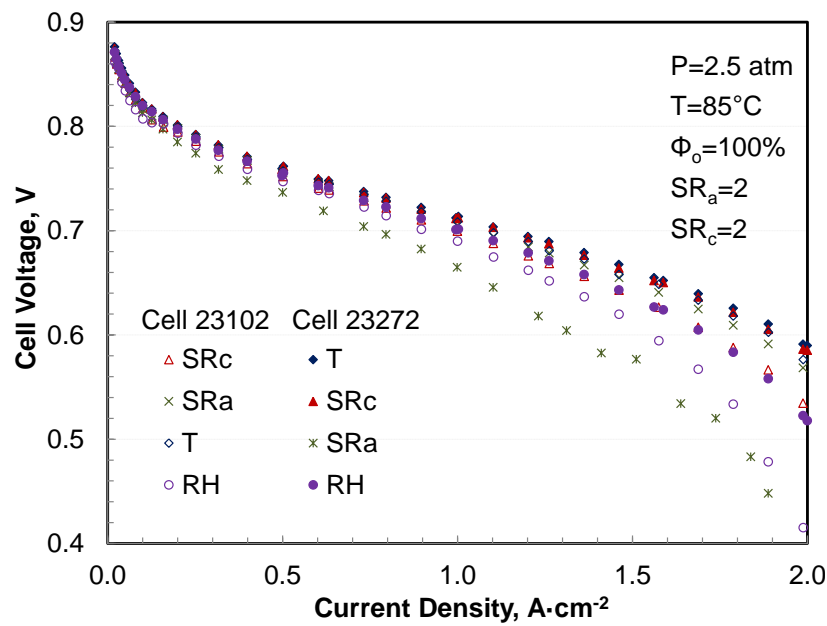

(a) Variability in polarization curves

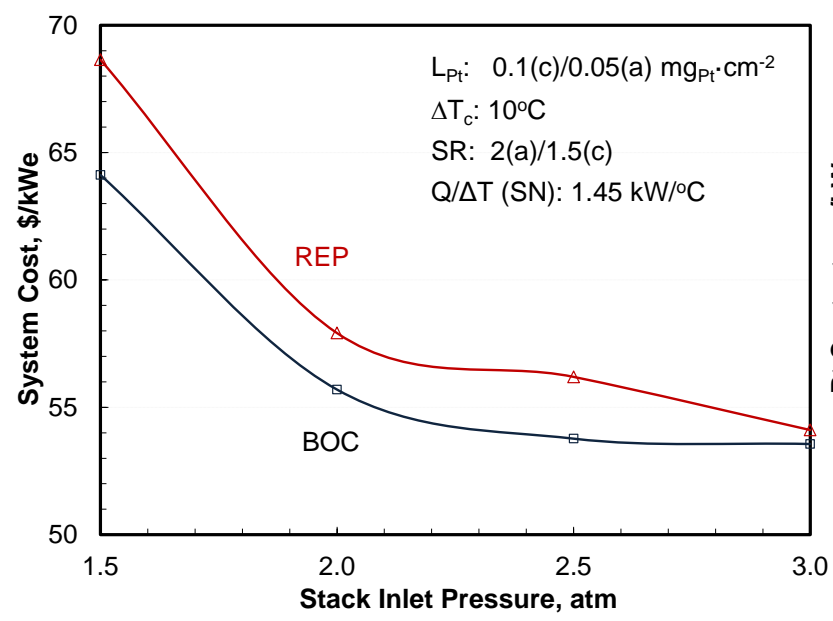

(c) System cost

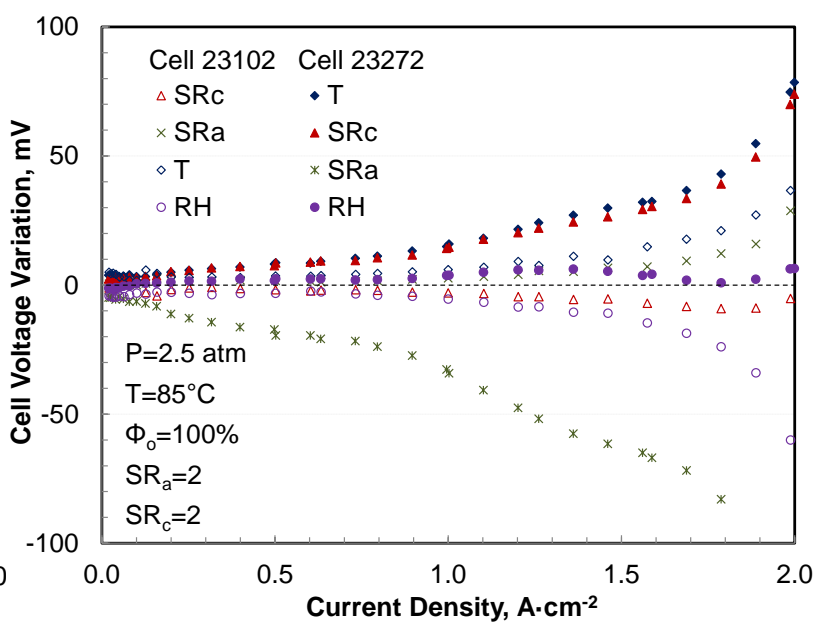

(b) Variability in cell voltage from the mean

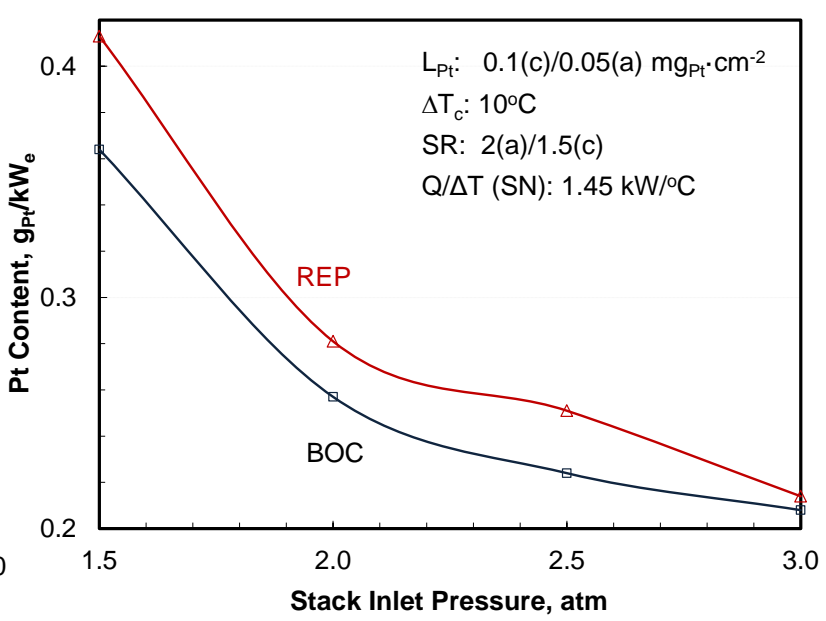

(d) Pt content

Figure 7 Comparison of system cost and performance for representative (REP) and best-of-class (BOC) data 


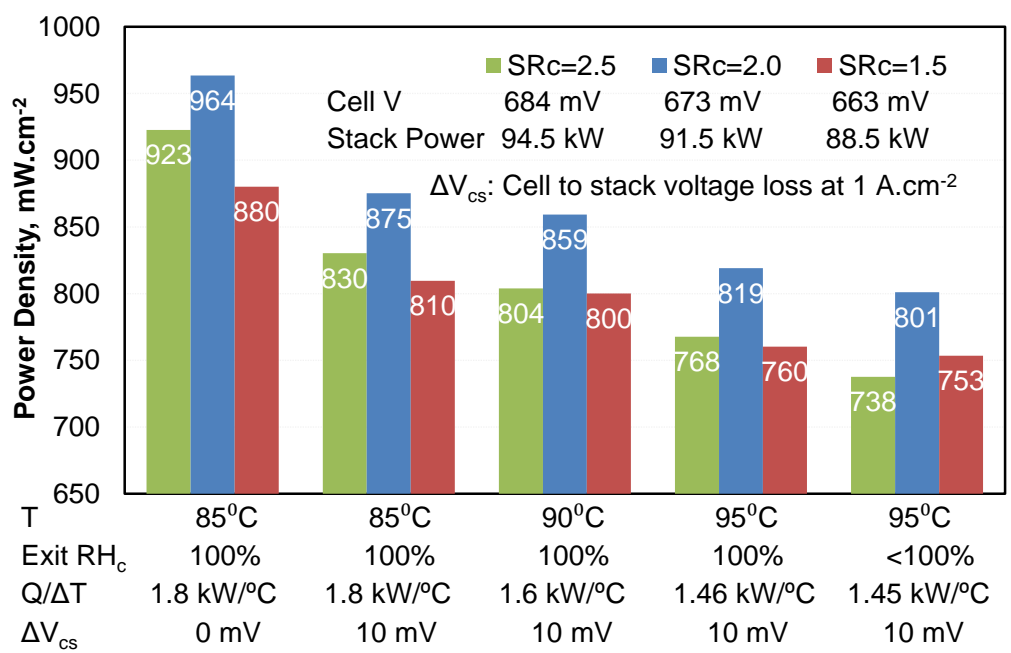

(a) BOC power density

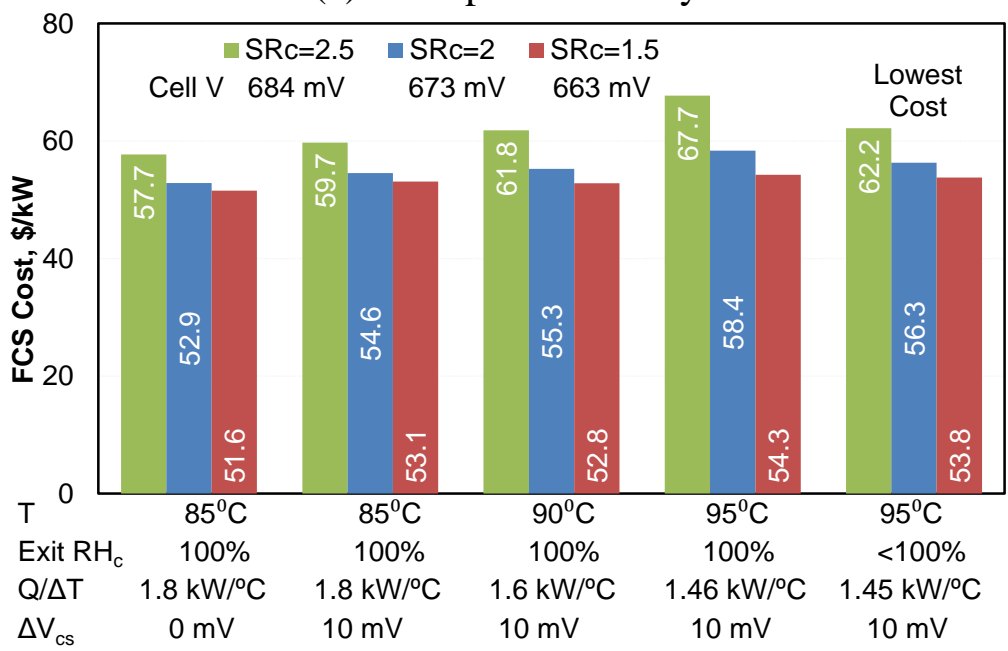

(b) Systematic increase in FCS cost

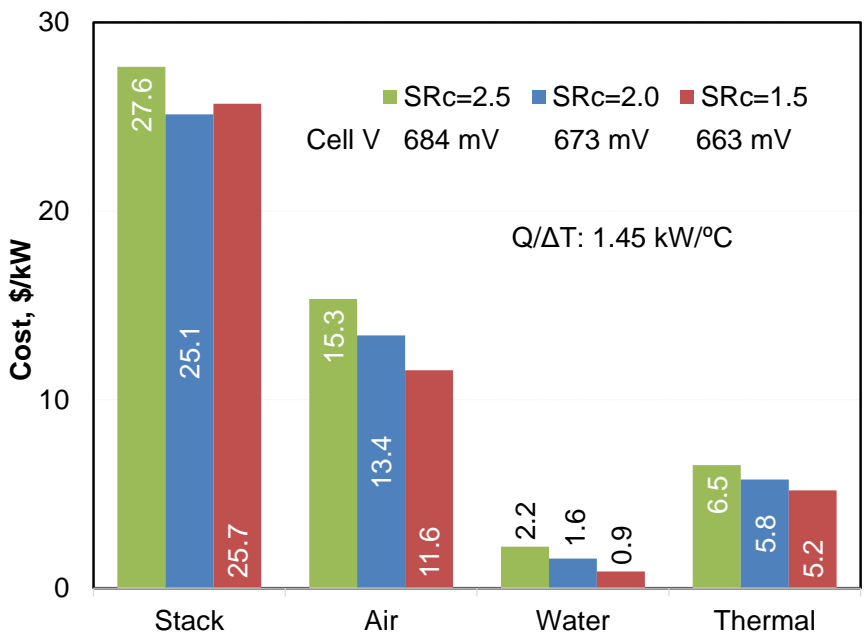

(c) Cost breakdown for cluster 5 conditions

Figure 8 Waterfall charts showing changes in power density and FCS cost due to cell-to-stack voltage degradation, rise in coolant temperature, and relaxation of $100 \%$ exit RH constraint 